\title{
Hindering the formation and promoting the dispersion of medical biofilms: non- lethal effects of seagrass extracts
}

\author{
Luca De Vincenti ${ }^{1}$, Yvana Glasenapp², Cristina Cattò ${ }^{1}$, Federica Villa ${ }^{1 *}$ (D), Francesca Cappitelli ${ }^{1}$ and
} Jutta Papenbrock ${ }^{2}$

\begin{abstract}
Background: Biofilms have great significance in healthcare-associated infections owing to their inherent tolerance and resistance to antimicrobial therapies. New approaches to prevent and treat unwanted biofilms are urgently required. To this end, three seagrass species (Enhalus acoroides, Halophila ovalis and Halodule pinifolia) collected in Vietnam and in India were investigated for their effects in mediating non-lethal interactions on sessile bacterial (Escherichia coli) and fungal (Candida albicans) cultures. The present study was focused on anti-biofilm activities of seagrass extracts, without killing cells.
\end{abstract}

Methods: Methanolic extracts were characterized, and major compounds were identified by MS/MS analysis. The antibiofilm properties of the seagrass extracts were tested at sub-lethal concentrations by using microtiter plate adhesion assay. The performance of the most promising extract was further investigated in elegant bioreactors to reproduce mature biofilms both at the solid/liquid and the solid/air interfaces. Dispersion and bioluminescent assays were carried out to decipher the mode of action of the bioactive extract.

Results: It was shown that up to 100 ppm of crude extracts did not adversely affect microbial growth, nor do they act as a carbon and energy source for the selected microorganisms. Seagrass extracts appear to be more effective in deterring microbial adhesion on hydrophobic surfaces than on hydrophilic. The results revealed that non-lethal concentrations of E. acoroides leaf extract: i) reduce bacterial and fungal coverage by 60.9 and $73.9 \%$, respectively; ii) affect bacterial biofilm maturation and promote dispersion, up to $70 \%$, in fungal biofilm; iii) increase luminescence in Vibrio harveyi by 25.8\%. The characterization of methanolic extracts showed the unique profile of the E. acoroides leaf extract.

Conclusions: E. acoroides leaf extract proved to be the most promising extract among those tested. Indeed, the selected non-lethal concentrations of $E$. acoroides leaf extract were found to exert an antibiofilm effect on $C$. albicans and E. coli biofilm in the first phase of biofilm genesis, opening up the possibility of developing preventive strategies to hinder the adhesion of microbial cells to surfaces. The leaf extract also affected the dispersion and maturation steps in C. albicans and E. coli respectively, suggesting an important role in cell signaling processes.

Keywords: Seagrass extracts, Non-lethal concentrations, Antibiofilm activity, Escherichia coli, Candida albicans

\footnotetext{
* Correspondence: federica.villa@unimi.it

${ }^{1}$ Dipartimento di Scienze per gli Alimenti, la Nutrizione e l'Ambiente,

Università degli Studi di Milano, via Celoria 2, 20133 Milan, Italy

Full list of author information is available at the end of the article
}

(c) The Author(s). 2018 Open Access This article is distributed under the terms of the Creative Commons Attribution 4.0 International License (http://creativecommons.org/licenses/by/4.0/), which permits unrestricted use, distribution, and reproduction in any medium, provided you give appropriate credit to the original author(s) and the source, provide a link to the Creative Commons license, and indicate if changes were made. The Creative Commons Public Domain Dedication waiver (http://creativecommons.org/publicdomain/zero/1.0/) applies to the data made available in this article, unless otherwise stated. 


\section{Background}

The ability of microorganisms to colonize surfaces and develop into highly organized communities enclosed in a self-produced polymeric matrix is the predominant growth modality in both nature and artificial systems. Such lifestyle is called biofilm and it is characterized by alterations in microbial phenotypes with respect to growth rates and gene transcriptions [1-3].

Biofilms have great significance for public health, representing $65-80 \%$ of microbial diseases currently treated by physicians in the developed world $[4,5]$. The presence of indwelling medical devices further increases the risk for biofilm formation and subsequent infection [6]. The bacterium Escherichia coli and the polymorphic fungus Candida albicans are among the most frequent cause of bloodstream infections, and the predominant microorganisms isolated from infected medical devices $[7,8]$. These biofilms, as any other biofilm, exhibit dramatically decreased susceptibility to antimicrobial agents and resistant to the host immune clearance, which increases the difficulties for the clinical treatment of infections [9-11]. Furthermore, the antimicrobial arena is experiencing a shortage of lead compounds, and growing negative consumer perception against synthetic products has led to the search for more natural solutions [12].

In this context, it has been reported that plant-derived extracts exhibit good antibiofilm properties against a range of microorganisms [13-15]. However, in the past, these extracts were mainly screened by focusing on their lethal effects [16-18] disregarding their activity at non-lethal concentrations. At these concentrations, plant-derived extracts may reveal elegant mechanisms to sabotage the sessile lifestyle, manipulating the expression of stage-specific biofilm phenotypes [19]. For instance, by affecting the cellular ability to attach to surfaces and by mystifying intercellular signals, the biofilm cascade might be hampered. Thus, non-lethal concentrations of plant-derived extracts can inspire innovative, eco-friendly and safe strategies aim at treating deleterious biofilms. Interfering with specific key steps that orchestrate biofilm genesis might offer new ways to disarm microorganisms without killing them, sidestepping drug resistance [4].

Seagrasses, which belong to the halophytes, represent a functional group of underwater marine flowering plants that have developed several strategies to survive and reproduce in environments where the salt concentration is around $200 \mathrm{mM} \mathrm{NaCl}$ or more [20]. As these plants grow in very high saline conditions, it is predicted that they could possess rare and new activities not reported for their terrestrial relatives [21, 22]. Indeed, metabolomic studies have shown that increased salinity leads to changes in conserved and divergent metabolic responses in halophytes [23-25]. Moreover, interesting activities of seagrass extracts, including antibacterial, antifungal, antialgal, antioxidant, anti-inflammatory, insecticidal, antimalarial and vasoprotective properties, have been reported [26-28].

Thus, the well described properties of seagrasses extracts offer a promising framework for investigating novel antibiofilm activities at non-lethal concentrations.

The present study explores, for the first time, the effect of extracts from different seagrasses (namely, leaves and roots from Enhalus acoroides Rich. ex Steud., Hydrocharitaceae, leaves of Halophila ovalis (R.Br.) Hook.f., Hydrocharitaceae, and leaves of Halodule pinifolia (Miki) Hartog, Cymodaceaceae) in mediating non-lethal interactions on sessile Candida albicans and Escherichia coli cultures, selected as model systems for fungal and bacterial biofilm infections, respectively. The work focuses on investigating the antibiofilm performance of seagrass extracts at sub-inhibitory concentrations, studying how they affect biofilm functional traits (such as adhesion, biofilm maturation, dispersal and quorum sensing), and induce cellular responses other than those associated with antimicrobial activities.

\section{Methods \\ Plant material and extraction}

Three species of seagrasses (leaves and roots from Enhalus acoroides Rich. ex Steud., Hydrocharitaceae, leaves of Halophila ovalis (R.Br.) Hook.f., Hydrocharitaceae, and leaves of Halodule pinifolia (Miki) Hartog, Cymodaceaceae) were collected in Vietnam and India and air-dried in a dark place (Table 1). Enhalus acoroides and Halophila ovalis were collected and identified by Xuan-Vy Nguyen, Department of Marine Botany, Institute of Oceanography, Vietnam Academy of Science and Technology, Nha Trang City, Vietnam, based on morphological characters and controlled by ITS molecular marker analysis [29]. Specimens of Enhalus acoroides are stored in the herbarium of the Institute of Botany, Hannover, Germany (Specimen number: EA20130301). Halodule pinifolia was collected by Jutta Papenbrock and further identified by Thirunavakkarasu Thangaradjou, Centre of Advanced Study in Marine Biology, Annamalai University, Parangipettai, Tamilnadu, India, based on morphological characters and controlled by ITS molecular marker analysis [30]. Specimens are stored in the herbarium of the Annamalai University, Parangipettai, Tamilnadu, India.

The plants were separated into different organs (leaves and roots), and samples were cooled with liquid nitrogen and ground to a fine powder using a bead mill (Retsch), three times for $10 \mathrm{~s}$ at a frequency of 30/s. The samples were stored at $-80{ }^{\circ} \mathrm{C}$ prior to analysis. Crude extracts were obtained using $80 \%$ methanol $(\mathrm{MeOH})$ as solvent. Around $50 \mathrm{mg}$ of powdered seagrass material was weighed in a reaction tube and extracted with $800 \mu \mathrm{l} 80 \% \mathrm{MeOH}$ 
Table 1 Seagrass species and information about collection sites

\begin{tabular}{lllll}
\hline Species & Plant organ & Collection site & GPS & Collection date \\
\hline Enhalus acoroides & Leaf & Nha Trang Bay, Vietnam & $109.209208^{\circ} \mathrm{E}$ & $12.158073^{\circ} \mathrm{N}$ \\
Enhalus acoroides & & Nha Trang Bay, Vietnam & $109.209208^{\circ} \mathrm{E}$ & 19.04 .2011 \\
& Root & Nha Trang Bay, Vietnam & $12.158073^{\circ} \mathrm{N}$ & 19.04 .2011 \\
Halophila ovalis & Leaf & & $109.209208^{\circ} \mathrm{E}$ & 19.04 .2011 \\
& & Chilika Lagoon, India & $85.418073^{\circ} \mathrm{N}$ & $19.775105^{\circ} \mathrm{N}$ \\
Halodule pinifolia & Leaf & & 16.02 .2010 \\
& & & \\
\hline
\end{tabular}

for $10 \mathrm{~min}$ with regular shaking. Then the extract was centrifuged for $5 \mathrm{~min}$ at $18000 \mathrm{x} \mathrm{g}$ and the supernatant transferred into a new reaction tube. These steps were repeated three times with $400 \mu \mathrm{l} 80 \% \mathrm{MeOH}$ each. The supernatants were collected in the same reaction tube and stored at $-20{ }^{\circ} \mathrm{C}$. Phosphate buffered saline (PBS, $0.01 \mathrm{M}$ phosphate buffer, $0.0027 \mathrm{M}$ potassium chloride $0.137 \mathrm{M}$, sodium chloride, Fisher Scientific) was used to obtain several concentrations of each crude extract: 100, 10, 1, 0.1, 0.01 and $0.001 \mathrm{mg} / \mathrm{l}$.

\section{Microbial strains and growth media}

The microbial strains Candida albicans SC5314 (ATCC MYA-2876) and Escherichia coli K-12 wild-type strain (ATCC 25404) were selected as model systems for fungal and bacterial biofilms respectively. C. albicans and E. coli strains were stored at $-80{ }^{\circ} \mathrm{C}$ in suspensions containing $50 \%$ glycerol and $2 \%$ peptone, and were routinely grown in amino acid-free yeast nitrogen base (YNB, Sigma-Aldrich) supplemented with $0.5 \%$ glucose (YNBG, Conda) and Luria-Bertani broth (LB, Sigma-Aldrich), respectively, for $16 \mathrm{~h}$ at $30^{\circ} \mathrm{C}$.

\section{Quantification of total flavonoid contents (TFC)}

The total flavonoid content of the seagrass extracts was measured in 96-well plate according to a modified protocol from Dudonné et al. [31]. The wells were filled with $150 \mu \mathrm{l} \mathrm{H}_{2} \mathrm{O}$ each. Dilutions of the methanolic seagrass extracts (1:2) were prepared and $25 \mu \mathrm{l}$ of sample were filled in one well, with four replicates. A calibration curve with catechin hydrate with the following concentrations was prepared in $80 \% \mathrm{MeOH}$ : 0, 10, 25, 50, 100, 125, 250 and $400 \mu \mathrm{g} / \mathrm{ml}$. The calibration curve was placed on the plate in triplicate. In the next step, $10 \mu \mathrm{l}$ $\mathrm{NaNO}_{2} 3.75 \%$ were added into each well and incubated for $6 \mathrm{~min}$. Afterwards, $15 \mu \mathrm{l}$ of $\mathrm{AlCl}_{3} 10 \%$ were added and incubated for $10 \mathrm{~min}$. In the last step, $50 \mu \mathrm{l}$ of $\mathrm{NaOH} 1 \mathrm{M}$ were added and the absorption was measured at $510 \mathrm{~nm}$ in a microplate reader (Biotek, Winooski, USA). The slope of the calibration curve was used to calculate the total flavonoid content in mg catechin equivalent.

\section{Quantification of total phenolic contents (TPC)}

To measure the total phenolic acid content, a modified protocol after Dewanto et al. [32] was used with the same extracts described above. 96-well microtiter plate were filled with $100 \mu \mathrm{l} \mathrm{H}_{2} \mathrm{O}$ each. From each sample, $10 \mu \mathrm{l}$ were added; seagrass extracts were diluted 1:2. A gallic acid calibration curve with the following concentration was used: $0,5,10,25,50,75,100,125$ and $250 \mu \mathrm{g} / \mathrm{ml}$. Next, $100 \mu \mathrm{l} \mathrm{Na} \mathrm{CO}_{3} 7 \%$ were added and the plate was incubated for $100 \mathrm{~min}$ in the dark. The absorption was measured at $765 \mathrm{~nm}$ in a microplate reader. With the slope of the gallic acid calibration curve, the concentration of phenolic acids was calculated in $\mathrm{mg}$ gallic acid equivalent.

\section{Determination if the oxygen radical absorbance capacity (ORAC)}

The analysis of the oxygen radical absorbance capacity (ORAC) was conducted according to a protocol based on Huang et al. (2002) [33] and Gillespie et al. [34] with the same extracts. A black 96-well microtiter was used and the wells were filled with $120 \mu$ l fluorescein (112 $\mathrm{nM}$ ) in phosphate buffer (75 mM, pH 7.4). Of each sample and the standard curve, $20 \mu \mathrm{l}$ were added in each well. The standard curve of 6-hydroxy-2, 5,7,8-tetramethylchroman-2-carboxylic acid (Trolox) was prepared in phosphate buffer with the following concentrations: 6.25, 12.5, 25 and $50 \mu \mathrm{M}$. Seagrass extracts were diluted 1:200 with methanol $80 \%$. The microtiter plate was incubated for $15 \mathrm{~min}$ at $37{ }^{\circ} \mathrm{C}$. The fluorescence was then measured at $485 / 520 \mathrm{~nm}$ as time point zero. Next, $80 \mu \mathrm{l}$ of 2,2'-azobis(2-amidino-propane) dihydrochloride $(62 \mathrm{mM})$ were added and the fluorescence was measured every minute for $80 \mathrm{~min}$. The ORAC value was calculated as the difference between time point zero and $80 \mathrm{~min}$ and quantified with the Trolox standard curve.

\section{LC-MS analysis}

LC-MS analysis was performed on a Shimadzu HPLC system (controller CBM-20A, two pumps LC-20 AD, a column oven CTO-20 AC and a photo diode array detector SPD-M20A; Shimadzu, Darmstadt, Germany) 
coupled to a Triple Tof 4600 mass spectrometer (AB Sciex, Canby, USA). The separation of extracted compounds was realised on a Knauer Vertex Plus column $(250 \times 4 \mathrm{~mm}, 5 \mu \mathrm{m}$ particle size, packing material ProntoSIL 120-5 C18-H) with precolumn (Knauer, Berlin, Germany). The column oven temperature was set to $30{ }^{\circ} \mathrm{C}$ and $25 \mu \mathrm{l}$ of undiluted methanolic seagrass extract prepared as described above was injected. The solvent flow rate was $0.8 \mathrm{ml} / \mathrm{min}$. In this time, a gradient was run from 10 to $90 \%$ B from minute 0 to 35 , 2 min of $90 \%$ B, switch to $10 \%$ B in 1 min and subsequent equilibration at $10 \%$ B for 2 min. Solvent A (water) and B (methanol) were both supplemented with $2 \mathrm{mM}$ ammonium acetate and $0.01 \%$ acetic acid. Mass spectra were monitored between 100 and $800 \mathrm{Da}$ in negative ionisation mode. In addition, MS/MS spectra were generated with a collision energy of $-30 \mathrm{eV}$ and measured between 50 and $800 \mathrm{Da}$. Spectra for the most prominent peaks were compared to database entries in MassBank [35] and ReSpect [36] for identification.

\section{Planktonic growth in the presence of seagrass extracts as the sole source of carbon and energy}

The ability of C. albicans and E. coli planktonic cells to grow in the presence of each extract as the sole carbon and energy source was tested using YNB and M9 (Sigma-Aldrich) mineral medium, respectively, supplemented with the highest working extract concentration: $100 \mathrm{mg} / \mathrm{l}$. Then a $100 \mu \mathrm{l} \mathrm{mix} \mathrm{of} \mathrm{mineral} \mathrm{medium} \mathrm{to-}$ gether with $45 \mu \mathrm{l}(3 \% \nu / \mathrm{v})$ of the overnight culture (final concentration $10^{8}$ cells $/ \mathrm{ml}$ ) and the highest concentration of each marine plant extract were used to fill each well of 96-well plates (Thermo Fisher Scientific) and incubated for $48 \mathrm{~h}$ at $30{ }^{\circ} \mathrm{C}$. A medium complemented with cells and glucose $(5 \mathrm{~g} / \mathrm{l})$, and medium without cells, were used as positive and negative controls, respectively. Microbial growth was monitored using the PowerWave XS2 microplate reader (Biotek) measuring the absorbance at $600 \mathrm{~nm}\left(\mathrm{~A}_{600}\right)$ every $10 \mathrm{~min}$. Six biological replicates of each treatment were performed. The obtained data were normalized to the negative control and reported as the mean of these.

\section{Growth inhibition assay in the presence of seagrass extracts}

The ability of the seagrass extracts to inhibit the planktonic growth of the selected microorganisms was investigated. For this, C. albicans and E. coli were grown YNBG and LB broth respectively without (positive control) and with the highest working concentrations (10 and $100 \mathrm{mg} /$ l) in 96-well plates (Thermo Fisher Scientific). Growth curves at $30{ }^{\circ} \mathrm{C}$ were generated using Infinite ${ }^{\circ}$ F200 PRO microplate reader (TECAN, Mannedorf, Switzerland) by measuring the optical density at $600 \mathrm{~nm}\left(\mathrm{OD}_{600}\right)$ every
$60 \mathrm{~min}$ for $30 \mathrm{~h}$ in wells inoculated with $45 \mu \mathrm{l}(3 \% \mathrm{vol} / \mathrm{vol})$ of an overnight culture (approximately $10^{8}$ cells $/ \mathrm{ml}$ ). The negative control was represented by PBS supplemented with $45 \mu \mathrm{l}(3 \% \mathrm{vol} / \mathrm{vol})$ of the overnight culture. The polynomial Gompertz model [37] was used to fit the growth curves to calculate the maximum specific growth rate $\left(\mathrm{A}_{600} / \mathrm{min}\right)$, using GraphPad Prism software (version 5.0, San Diego, CA, USA). Five biological replicates of each treatment were performed.

\section{Microplate-based biofilm assay}

The antibiofilm activity of seagrass extracts was assessed quantitatively as previously reported by Villa et al. [38]. Briefly, $200 \mu \mathrm{l}$ of PBS containing $10^{8}$ cells $/ \mathrm{ml}$ supplemented with 0 (positive control), 100, 10, 1, 0.1, 0.01, and $0.001 \mathrm{mg} / \mathrm{l}$ of each crude extract were placed in hydrophobic and hydrophilic 96-well polystyrene-based microtiter plates (Thermo Fisher Scientific). After an incubation time of $24 \mathrm{~h}$ at $20{ }^{\circ} \mathrm{C}, \mathrm{C}$. albicans and E. coli planktonic cells were removed and adhered cells were stained using $0.1 \mathrm{mg} / \mathrm{ml}$ of Fluorescent Brightener 28 vital dye (Sigma-Aldrich) or 4', 6-diamidino-2-phenylindole (DAPI, Sigma-Aldrich) in PBS, respectively. After $20 \mathrm{~min}$ staining in the dark at room temperature the microtiter plates were washed twice with $200 \mu \mathrm{l}$ PBS and the fluorescence intensity due to adhered cells was measured using a fluorescence microplate reader (TECAN, Manneford, Switzerland) at excitation wavelength of $335 \mathrm{~nm}$ and emission wavelength of $433 \mathrm{~nm}$. A standard curve of fluorescence intensity versus cell number was determined and used to quantify the antibiofilm performance of the crude extracts. Percentage reduction with respect to the positive control is calculated as (treated data -control data) $\times 100$ / control data. Cattò et al. [39] proposed the following anti-adhesion ranges computing the percentage reduction in comparison to the negative control: $\leq 20 \%$ without anti-adhesion activity; between 20 and $30 \%$ and 30 and $40 \%$ low anti-adhesion activity and with moderate anti-adhesion activity respectively; $\geq 40 \%$ adhered cells with excellent anti-adhesion activity. Five biological replicates were performed for each condition and a percentage reduction in comparison to the negative control was calculated as (treated data - positive control data) $\times 100 /$ positive control data. The experiment was repeated three times.

\section{Biofilm growth at the solid/liquid interface}

The most promising plant extracts were screened for their effects on biofilm development. C. albicans biofilm was grown in the CDC biofilm reactor (Biosurface Technologies, Bozeman, MT, USA) as previously described by Villa et al. [40]. Briefly, two bioreactors hosting 24 polycarbonate coupons (to simulate a hydrophobic surface) were filled with YNBG and $1 \mathrm{ml}$ of overnight 
planktonic culture (approximately $10^{8}$ cells $/ \mathrm{ml}$ ) and, in one of them, $0.01 \mathrm{mg} / \mathrm{l}$ of $E$. acoroides leaf extract was added. Bioreactors were maintained under static conditions (no flow) for $24 \mathrm{~h}$ under mild stirring at $37^{\circ} \mathrm{C}$, promoting fungal adhesion to the surface of the removable polycarbonate coupons. After that, the dynamic phase was initiated and diluted YNGB was fluxed for $48 \mathrm{~h}$ at flow rate of $250 \mathrm{ml} / \mathrm{h}$. Biofilm growth in the absence (positive control) and presence of the extract was evaluated by quantification of the biomass. At different time steps (24, 48 and $72 \mathrm{~h}$ ) some polycarbonate coupons were collected in aseptic conditions and resuspended in $3 \mathrm{ml}$ of PBS each. Subsequently, serial dilutions were carried out, and $10 \mu \mathrm{l}$ were inoculated in petri dishes containing Tryptic Soy Broth medium (TSB, Sigma-Aldrich) complemented with agar (Merck) following the drop counting method. After $12 \mathrm{~h}$ at $30^{\circ} \mathrm{C}, \mathrm{C}$. albicans colonies were counted and the data obtained were normalized to the coupon area, and means were reported. The same protocol was used to obtain mature biofilm of $E$. coli, using LB as a medium, and evaluating $10 \mathrm{mg} / \mathrm{l}$ of $E$. acoroides leaf extract. Each experiment was repeated three times.

\section{Biofilm dispersion assay}

Mature C. albicans biofilm was grown in the CDC reactor in the absence (positive control) and presence and of $0.01 \mathrm{mg} / \mathrm{l}$ of $E$. acoroides leaf extract as reported below. As previously described by Cattò et al. [41], after $72 \mathrm{~h}$ polycarbonate coupons were collected, immersed in $27 \mathrm{ml}$ of PBS for one minute at room temperature, serial dilutions were carried out and $10 \mu \mathrm{l}$ were inoculated in petri dishes containing TSB supplemented with agar (Merck) following the drop counting method. After $12 \mathrm{~h}$ at $30{ }^{\circ} \mathrm{C}, \mathrm{C}$. albicans colonies were counted and the percentage of biofilm dispersion was calculated as (number of viable cells from bulk $\mathrm{PBS} \times 100$ ) / (number of viable cells from bulk PBS + number of viable cells from the coupon biofilm) and means were reported. Three biological replicates were performed for each treatment and six technical replicates were performed for each experiment. The experiment was performed three times.

\section{Biofilm growth at the solid/air interface}

E. coli biofilm was grown on a sterile polycarbonate membrane (PC, Whatman Nucleopore, diameter $2.5 \mathrm{~cm}$, pore diameter $0.2 \mu \mathrm{m}$ ) as previously described by Garuglieri et al. [42]. Briefly, $0.05 \mathrm{ml}$ of an overnight culture (approximately $10^{6}$ cells $/ \mathrm{ml}$ ) were inoculated at the center of a sterile polycarbonate membrane and, when the inoculum was completely dried, the membrane was carefully put inside a transwell structure (ThinCert ${ }^{\text {th }}$ Cell Culture Inserts with translucent PET membrane - Greiner bio-one) inlaid in a 6 well culture plate (Greiner bio-one). One $\mathrm{ml}$ of LB medium was inoculated in the basolateral compartment (plate well). Biofilm formation was performed at $37{ }^{\circ} \mathrm{C}$ in aerobic conditions for $16 \mathrm{~h}$. At different time points $(0,4$, $6,8,16 \mathrm{~h}$ ) some membranes were removed, biofilm was scraped off using a sterile loop, put inside a tube containing $1 \mathrm{ml}$ of PBS and then homogenized twice using a homogenizer (IKA T10 basic Ultra-Turrax - Cole-Parmer Instrument Company). Then serial dilutions were prepared and $10 \mu \mathrm{l}$ were inoculated in petri dishes containing LB with agar following the drop counting method. After $12 \mathrm{~h}$ at $37^{\circ} \mathrm{C}$, E. coli colonies were counted and the biomass was quantified. This assay was assessed under three experimental conditions: i) treatment 1 : growth in contact with $1 \mathrm{ml}$ of LB with $10 \mathrm{mg} / \mathrm{l}$ of $E$. acoroides leaf extract for $16 \mathrm{~h}$; ii) treatment 2: overnight culture grown with $10 \mathrm{mg} / \mathrm{l}$ of $E$. acoroides leaf extract, and then growth in contact with $1 \mathrm{ml}$ of LB for $16 \mathrm{~h}$; iii) treatment 3: overnight culture grown with $10 \mathrm{mg} / \mathrm{l}$ of $E$. acoroides leaf extract, and then growth in contact with $1 \mathrm{ml}$ of LB with $10 \mathrm{mg} / \mathrm{l}$ of $E$. acoroides leaf extract for $16 \mathrm{~h}$. In the positive control, the microorganisms grew in $1 \mathrm{ml} \mathrm{LB}$ inside a basolateral well for $16 \mathrm{~h}$ without the extract. The data obtained were divided by the area of the membrane, and the means were reported. The experiment was repeated three times.

\section{B2ioluminescence assay using Vibrio harveyi}

Two hundred $\mu$ l of autoinducer bioassay (AB) mineral medium $\left(0.3 \mathrm{M} \mathrm{NaCl}, 0.05 \mathrm{M} \mathrm{MgSO}_{4}, 0.5 \%\right.$ casein

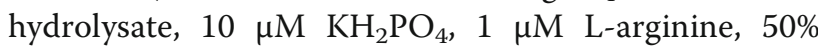
glycerol, $0.01 \mu \mathrm{g} / \mathrm{ml}$ riboflavin, $1 \mu \mathrm{g} / \mathrm{ml}$ thiamine. $\mathrm{pH} 7$. Sigma-Aldrich) containing $10 \%(\mathrm{~V} / \mathrm{V})$ of a tenfold dilution of an overnight culture of Vibrio harveyi BB170 (ATCC BAA-1117) grown in AB medium were supplemented with $10 \mathrm{mg} / \mathrm{l}$ of $E$. acoroides leaf extract respectively, and were placed in hydrophobic 96-well polystyrene-based microtiter plates (Thermo Fisher Scientific) with transparent bottom. The positive control was an $\mathrm{AB}$ mineral medium supplemented with $10 \%(\mathrm{~V} /$ $\mathrm{V)}$ tenfold dilution of the overnight culture. Absorbance $\left(\mathrm{OD}_{600 \mathrm{~nm}}\right)$ and luminescence were measured using a microplate reader $\left(\mathrm{VICTOR}^{\mathrm{Tm}} \mathrm{X}\right.$, Perkin Elmer, USA) every $8 \mathrm{~h}$ for $24 \mathrm{~h}$, incubating the microtiter plate at $30{ }^{\circ} \mathrm{C}$ during the experiment. The data obtained were normalized to the number of viable cells, divided by the area of the membrane, and the means reported. The experiment was repeated three times.

\section{Statistical analysis}

To evaluate statistically significant differences among samples, analysis of variance (ANOVA) via MATLAB software (Version 7.0, The MathWorks Inc., Natick, USA) was applied. Tukey's honestly significant different test (HSD) was applied for pairwise comparison to 
establish the significance of the data. Statistically significant results were represented by $P$ values $\leq 0.05$.

\section{Results}

Seagrass extracts contain phenolic compounds and show antioxidant capacities

The methanolic extracts from the seagrass material contained phenolic acids as well as flavonoids (Fig. 1a-b). The content of phenols and flavonoids was highest in $H$. pinifolia leaf extracts with $18.0 \pm 0.25$ and $14.3 \pm 0.25 \mathrm{mg} /$ g dry mass (DM), respectively. In E. acoroides, the root material showed higher amounts of total flavonoids and phenols than the leaf material. For all seagrass species, the content of phenolic acids was higher than the flavonoid content with respect to the DM.

Methanolic extracts from the four seagrass species were analyzed for their antioxidant capacity (Fig. 1c). All tested extracts had the ability to absorb oxygen radicals. H. pinifolia showed the highest activity with 97.7 $\pm 2.7 \mathrm{mg}$ Trolox equivalents (TE)/g DM. E. acoroides and $H$. ovalis leaf extracts showed similar antioxidant capacities with $70.2 \pm 4.1$ and $72.5 \pm 2.9 \mathrm{mg} \mathrm{TE} / \mathrm{g} \mathrm{DM}$, respectively. The root extract from $E$. acoroides displayed a lower ORAC value than the extract from the leaves $(45.1 \pm 3.2 \mathrm{mg} \mathrm{TE} / \mathrm{g} \mathrm{DM})$.

\section{LC-MS analysis of secondary metabolites}

$E$. acoroides, $H$. ovalis and $H$. pinifolia show different compositions of secondary metabolites (Fig. 2). The identification of individual compounds in the methanolic extracts was done via the comparison of MS/MS spectra with database entries. The three seagrass species showed different profiles of secondary metabolites, in this case mainly flavonoids and phenolic acids (Table 2). In E. acoroides leaves, three flavonoles based on kaempferol were found. In addition, two flavones (apigenin and luteolin), one phenolic acid (benzoic acid) and the saturated dicarboxylic acid azelaic acid were identified. The root extract of $E$. acoroides also contained two kaempferol-based flavonoles and luteolin and also a procyanidin and a flavanole (epicatechin). In $H$. ovalis three flavonoids and one phenolic acid was found. H. pinifolia contained several flavonoles, either based on kaempferol or quercetin and also epicatechin.

\section{Seagrass extracts are not used as carbon and energy source by C. albicans and E. coli and do not affect their planktonic growth}

C. albicans and E. coli planktonic cells grown only in the presence of medium supplemented with glucose were used as the positive control of the experiment (Fig. 3). Note that the mineral medium supplemented with the highest concentration of tested plant extracts did not promote the growth of the selected microorganisms.

The response of the planktonic growth of the selected microorganisms in the presence of the seagrass extracts at the highest concentrations (10 and $100 \mathrm{mg} / \mathrm{l}$ ) is reported in Figs. 4 and 5. C. albicans and E. coli growth rates (table in Figs. 4 and 5) showed that there are no statistically significant differences between the presence and the absence of the extracts obtained from every plant portion at any tested concentration. Therefore, concentrations $\leq 100 \mathrm{mg} / \mathrm{l}$ plant extract were used in the subsequent studies.

\section{E. acoroides leaf extract inhibits cell adhesion on a hydrophobic surface}

The percentage reduction of the number of adhered cells of $E$. coli and C. albicans on hydrophilic and hydrophobic surface in presence of non-lethal concentrations of seagrass extracts is showed in Fig. 6 . The results revealed that $E$. acoroides and $H$. ovalis were the most promising extracts for C. albicans, with excellent anti-adhesion activity, reducing fungal coverage up to $73.89 \pm 1.01 \%$ and $68.37 \pm$ $2.49 \%$ at 0.01 and $1 \mathrm{mg} / \mathrm{l}$, respectively. For E. coli, $10 \mathrm{mg} / \mathrm{l}$ of $E$. acoroides leaf extract was found to be the concentration with the highest reduction in cell adhesion (reduction
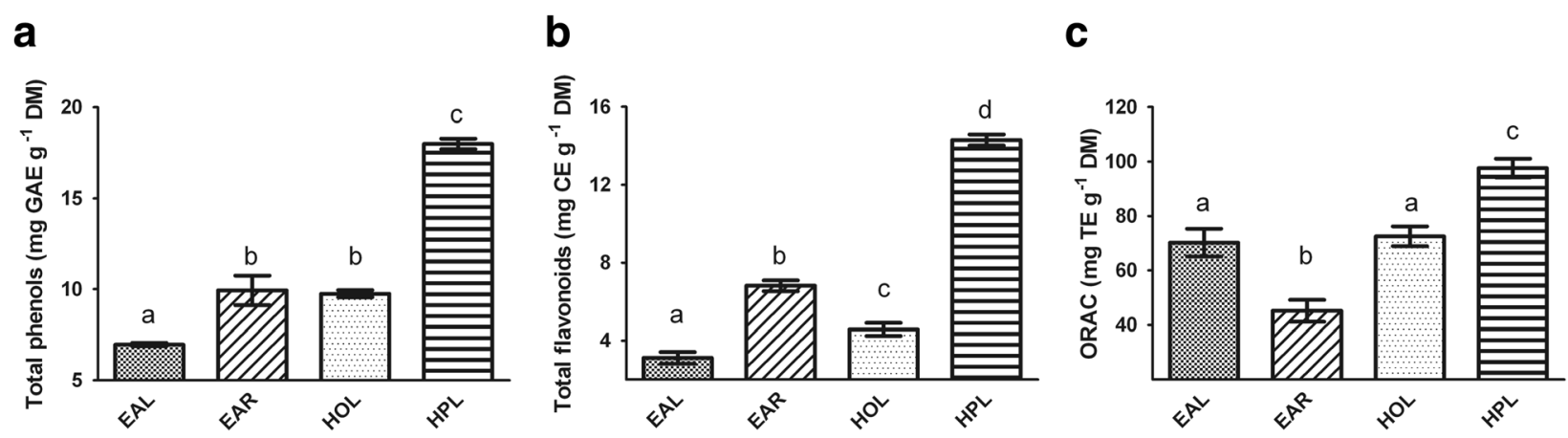

Fig. 1 Crude methanolic extracts were analyzed for (a) Total phenols in mg gallic acid equivalent (GAE) per g dry mass (DM), (b) Total flavonoids in $\mathrm{mg}$ catechin equivalent (CE) per $\mathrm{g} \mathrm{DM}$, and (c) ORAC in mg Trolox equivalents (TE) per g DM. Data represent the mean \pm SDs and different superscript letters indicate statistically significant differences (Tukey's HSD, $p \leq 0.05$ ) between the means of three independent measurements. $(\mathrm{EAL}=$ Enhalus acoroides leaf; $\mathrm{EAR}=$ Enhalus acoroides root; $\mathrm{HPL}=$ Halodule pinifolia leaf; $\mathrm{HOL}=$ Halophila ovalis leaf) 

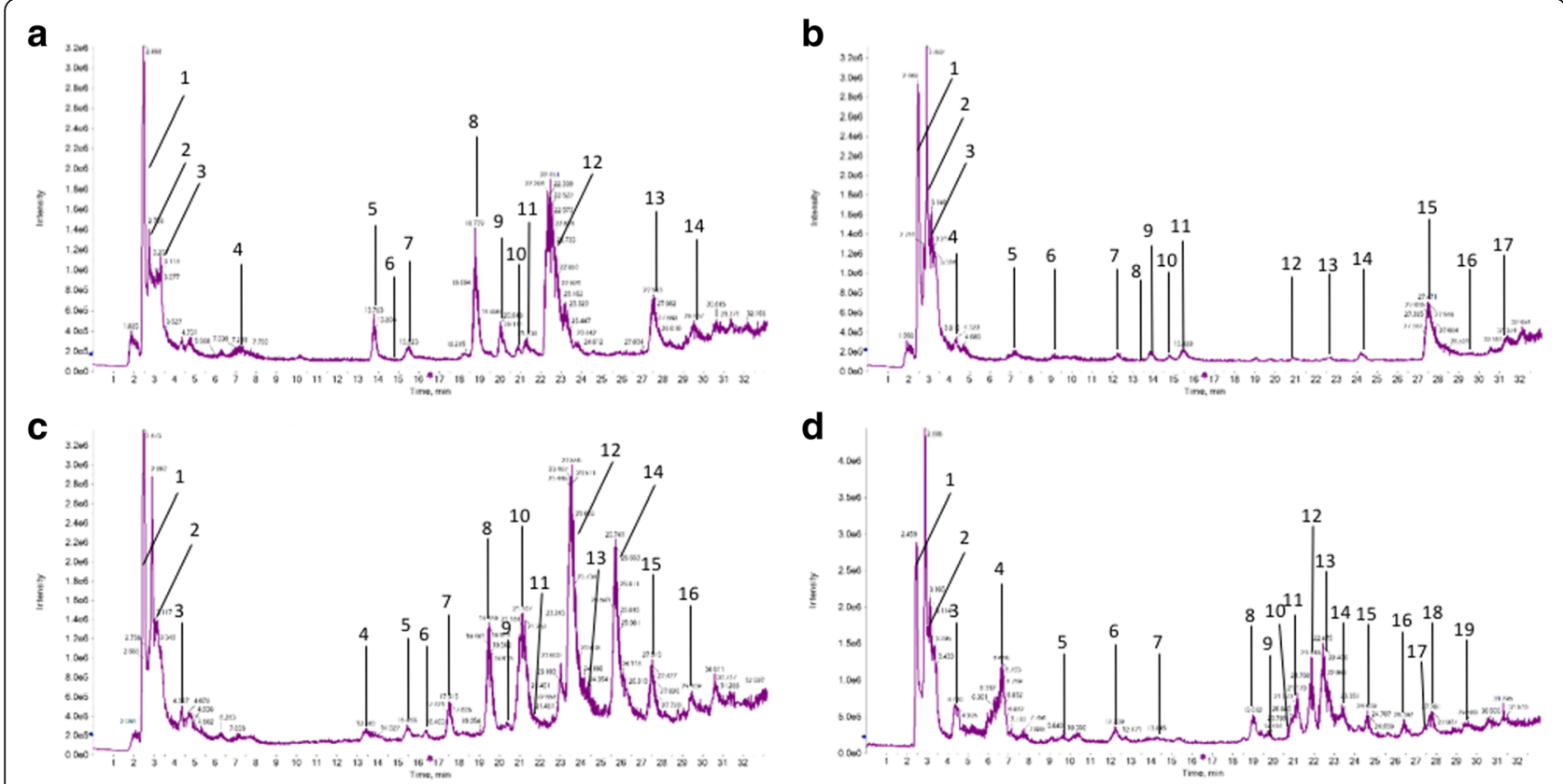

Fig. 2 Chromatograms from E. acoroides leaf extract (a), E. acoroides root extract (b), H. ovalis leaf extract (c) and H. pinifolia leaf extract (d) from minute $0-33$. The relative intensity of mass between 100 and 800 Da is shown. Numbers indicate putatively identified substances in Table 2

of bacterial coverage by $60.86 \pm 8.85 \%$ ). Therefore, $0.01 \mathrm{mg} /$ 1 and $10 \mathrm{mg} / \mathrm{l} E$. acoroides leaf extract were chosen as the best non-biocidal concentrations for $C$. albicans and $E$. coli respectively, and were used in the subsequent studies.

\section{E. acoroides leaf extract does not impact on biofilm} growth curves, but does induce biofilm dispersion in $C$. albicans and interfere with $\mathrm{Al} 2$

A CDC reactor was used as the laboratory scale model system to grow a complex and mature C. albicans biofilm in the absence and presence of $0.01 \mathrm{mg} / \mathrm{l}$ E. acoroides leaf extract, the most effective concentration obtained from the adhesion assay.

Results in Fig. 7a indicated a significant reduction in the number of viable cells adhered on coupon surfaces treated with the extract, compared to the untreated ones, after $24 \mathrm{~h}$ (reduction of fungal coverage up to $26.77 \pm 9.01 \%$ ). Coupons collected after 48 and 72 h showed no significant differences between the treated biofilm and the control.

A significant increase in the number of dispersed cells in the treated biofilm $(70 \pm 6.83 \%)$ was observed (Fig. 7b).

A colony biofilm assay was used to grow a complex and mature $E$. coli biofilm in the presence and absence of $10 \mathrm{mg} / \mathrm{l}$ E. acoroides. Results in Fig. 8 showed no significant reduction in the number of viable cells during biofilm formation on the membrane treated with the extract, compared to the untreated, after $18 \mathrm{~h}$ in all the experimental conditions. Treatment 3 showed a growth rate slowdown in the interval $6-8$, in which $E$. coli cells were in contact with the extract during both overnight growth and biofilm formation (reduction of cellular growth, compared to the control, up to $48.64 \pm 4.02 \%$ ). This growth curve was characterized by two exponential phases separated distinctly by an intermediate phase where the growth rate is very low. After that, at $16 \mathrm{~h}$ the number of viable cells was similar to the other treatments.

The effects of $10 \mathrm{mg} / \mathrm{l}$ of $E$. acoroides leaf extract on the cellular communication of $V$. harveyi were reported in Fig. 9. The results highlighted a significant increase in the relative luminescence emitted at time $8 \mathrm{~h}$ compared to the control $(25.75 \pm 7.49 \%)$.

\section{Discussion}

Biofilm resistance to antimicrobial agents is a major worldwide health care issue. Therefore, a successful reduction of surface colonization can be a potential strategy for the management of unwanted biofilms, especially on medical devices and work surfaces.

In this context, the use of plant-derived extracts to modulate biofilm genesis and dispersion may be a viable alternative. The present study is the first report describing the antibiofilm efficacy of non-lethal concentrations of $E$. acoroides, $H$. pinifolia and $H$. ovalis methanol extracts in counteracting microbial biofilms, highlighting the possibility that the selected seagrass species act as an extracellular signal mediating their biofilm activities.

E. coli and $C$. albicans were chosen as model systems for bacterial and fungal infections, respectively. E. coli 
Table 2 Individual compounds identified by comparison of MS/MS spectra with database entries in Enhalus acoroides leaf extract (A), E. acoroides root extract (B), Halophila ovalis leaf extract (C) and Halodule pinifolia leaf extract (D)

\begin{tabular}{|c|c|c|c|c|c|c|}
\hline No & RT & Mass & MS/MS & Name & Accession & Source \\
\hline \multicolumn{7}{|c|}{ A - E. acoroides leaf extract } \\
\hline 1 & 2.5 & 343.03 & $201.02,157.03,59.01$ & n. i. & - & - \\
\hline 2 & 2.7 & 312.12 & $179.05,132.06,89.02$ & n. i. & - & - \\
\hline 3 & 3.3 & 367.1 & $277.07,187.04,157.03$ & n. i. & - & - \\
\hline 4 & 7.2 & 134.04 & $107.03,92.02$ & Adenine & PT200393 & ReSpect \\
\hline 5 & 13.7 & 637.1 & $461.07,285.04$ & Kaempferol-3-glucuronide, mod. & PT209240 & ReSpect \\
\hline 6 & 14.8 & 275.15 & $233.12,119.05$ & n. i. & - & - \\
\hline 7 & 15.2 & 121.03 & $92.02,77.03$ & Benzoic acid & KO000321 & MassBank \\
\hline 8 & 18.6 & 527.02 & $285.04,241.00,96.96$ & n. i. & - & - \\
\hline 9 & 20.1 & 511.05 & $269.04,241.00,96.96$ & n. i. & - & - \\
\hline 10 & 20.8 & 187.09 & $169.08,125.09,97.06$ & Azelaic acid & KO000124 & MassBank \\
\hline 11 & 21.3 & 447.09 & 285.04 & Kaempferol-3-O-glucoside & PS042209 & ReSpect \\
\hline 12 & 22.5 & 461.07 & 285.04 & Kaempferol-3-glucuronide & PS092408 & ReSpect \\
\hline 13 & 27.5 & 285.04 & $151.00,133.03$ & Luteolin & PS040410 & ReSpect \\
\hline 14 & 29.5 & 269.04 & $225.05,151.00,117.03$ & Apigenin & PT203930 & ReSpect \\
\hline \multicolumn{7}{|c|}{ B - E. acoroides root extract } \\
\hline 1 & 2.4 & 343.03 & $201.02,157.03,59.01$ & n. i. & - & - \\
\hline 2 & 2.7 & 312.12 & $179.05,132.06,89.02$ & n. i. & - & - \\
\hline 3 & 2.9 & 377.08 & $341.11,179.05,119.03,89.02$ & Galactinol dihydrate, mod. & PT211910 & ReSpect \\
\hline 4 & 4.3 & 216.98 & $173.02,156.98,136.94,59.01$ & n. i. & - & - \\
\hline 5 & 7.2 & 134.04 & $107.03,92.02$ & Adenine & PT200393 & ReSpect \\
\hline 6 & 9.6 & 577.12 & $451.10,425.08,407.07,289.07,125.02$ & Procyanidin B2 & PT204580 & ReSpect \\
\hline 7 & 12.3 & 289.07 & $245.07,203.07,151.04,109.03$ & $+(-)$ Epicatechin & PT204560 & ReSpect \\
\hline 8 & 13.8 & 637.1 & $461.07,285.04$ & Kaempferol-3-glucuronide, mod. & PT209240 & ReSpect \\
\hline 9 & 14.0 & 469.08 & $275.02,193.05,178.02,149.06,96.96$ & n. i. & - & - \\
\hline 10 & 14.8 & 275.15 & $233.12,119.05$ & n. i. & - & - \\
\hline 11 & 15.3 & 121.03 & $92.02,77.03$ & Benzoic acid & KO000321 & MassBank \\
\hline 12 & 20.8 & 187.09 & $169.08,125.09,97.06$ & Azelaic acid & KO000124 & MassBank \\
\hline 13 & 22.6 & 461.07 & 285.04 & Kaempferol-3-glucuronide & PS092408 & ReSpect \\
\hline 14 & 24.1 & 299.05 & $284.03,256.03,133.03$ & Kaempferide & PT204030 & ReSpect \\
\hline 15 & 27.5 & 285.04 & $151.00,133.03$ & Luteolin & PS040410 & ReSpect \\
\hline 16 & 29.5 & 269.04 & $225.05,151.00,117.03$ & Apigenin & PT203930 & ReSpect \\
\hline 17 & 31.2 & 329.23 & $229.14,211.13,171.10$ & n. i. & - & - \\
\hline \multicolumn{7}{|c|}{$\mathrm{C}-\mathrm{H}$. ovalis leaf extract } \\
\hline 1 & 2.4 & 343.03 & $201.02,157.03,59.01$ & n. i. & - & - \\
\hline 2 & 2.9 & 377.08 & $341.11,179.05,119.03,89.02$ & Galactinol dihydrate, mod. & PT211910 & ReSpect \\
\hline 3 & 4.3 & 216.98 & $173.02,156.98,136.94,59.01$ & n. i. & - & - \\
\hline 4 & 13.3 & 261.04 & $217.05,189.05,133.02$ & n. i. & - & - \\
\hline 5 & 15.5 & 121.03 & $92.02,77.03$ & Benzoic acid & KO000321 & MassBank \\
\hline 6 & 16.3 & 306.17 & 288.16 & n. i. & - & - \\
\hline 7 & 17.5 & 479.08 & 316,02 & Myricetin-3-galactoside & PS092809 & ReSpect \\
\hline 8 & 19.5 & 463.09 & 301,03 & Quercetin-3-O-beta-D-galactoside & PS046509 & ReSpect \\
\hline 9 & 20.8 & 187.09 & $169.08,125.09,97.06$ & Azelaic acid & KO000124 & MassBank \\
\hline
\end{tabular}


Table 2 Individual compounds identified by comparison of MS/MS spectra with database entries in Enhalus acoroides leaf extract (A), E. acoroides root extract (B), Halophila ovalis leaf extract (C) and Halodule pinifolia leaf extract (D) (Continued)

\begin{tabular}{|c|c|c|c|c|c|c|}
\hline No & RT & Mass & MS/MS & Name & Accession & Source \\
\hline 10 & 21.1 & 317.02 & $271.02,149.02$ & n.i. & - & - \\
\hline 11 & 21.3 & 447.09 & 285.04 & Kaempferol-3-O-glucoside & PS042209 & ReSpect \\
\hline 12 & 23.5 & 301.03 & $255.03,165.02,133.03$ & n.i. & - & - \\
\hline 13 & 24.1 & 299.05 & $284.03,256.03,133.03$ & Kaempferide & PS040309 & ReSpect \\
\hline 14 & 25.7 & 285.04 & $239.03,185.06,143.05,117.03$ & Kaempferol & PR040027 & MassBank \\
\hline 15 & 27.5 & 285.04 & $285.04,151.00,133.02$ & Luteolin & PT204043 & ReSpect \\
\hline 16 & 29.4 & 269.04 & $225.05,151.00,117.03$ & Apigenin & PT203930 & ReSpect \\
\hline \multicolumn{7}{|c|}{ D - H. pinifolia leaf extract } \\
\hline 1 & 2.4 & 343.03 & $201.02,157.03,59.01$ & n. i. & - & - \\
\hline 2 & 2.9 & 377.08 & $341.11,179.05,119.03,89.02$ & Galactinol dihydrate, mod. & PT211910 & ReSpect \\
\hline 3 & 4.3 & 216.98 & $173.02,156.98,136.94,93.03,59.01$ & n. i. & - & - \\
\hline 4 & 6.6 & 473.07 & $311.04,293.03,179.03,149.01$ & n. i. & - & - \\
\hline 5 & 9.6 & 577.12 & $451.10,425.08,407.07,289.07,125.02$ & Procyanidin B2 & PT204580 & ReSpect \\
\hline 6 & 12.1 & 289.07 & $245.07,203.07,151.04,109.03$ & $+(-)$ Epicatechin & PT204560 & ReSpect \\
\hline 7 & 14.0 & 469.08 & $275.02,193.05,178.02,149.06,96.96$ & n. i. & - & - \\
\hline 8 & 19.1 & 641.17 & $473.13,311.07,167.03$ & n. i. & - & - \\
\hline 9 & 19.7 & 549.09 & $505.10,463.09,300.02,271.02,255.02$ & Quercetin-3-(6-malonyl)-glucoside & PT209340 & ReSpect \\
\hline 10 & 20.8 & 187.09 & $169.08,125.09,97.06$ & Azelaic acid & KO000124 & MassBank \\
\hline 11 & 21.1 & 505.09 & $463.08,300.02,271.02$ & Quercetin-3-O-beta-D-galactoside, mod. & PT204650 & ReSpect \\
\hline 12 & 21.8 & 463.08 & $300.03,271.02$ & Quercetin-3-O-beta-D-galactoside & PT204650 & ReSpect \\
\hline 13 & 22.4 & 433.07 & $300.02,271.02,255.03,179.00$ & Quercetin-3-arabinoside & PT209320 & ReSpect \\
\hline 14 & 23.4 & 447.09 & $284.03,255.03,227.03$ & Kaempferol-3-glucoside & PT209270 & ReSpect \\
\hline 15 & 24.6 & 417.08 & $284.03,255.03,227.03$ & Kaempferol-3-O-alpha-L-arabinoside & PT209220 & ReSpect \\
\hline 16 & 26.3 & 301.03 & $178.99,151.00,121.03,107.01$ & Quercetin & PT204090 & ReSpect \\
\hline 17 & 27.4 & 285.04 & $199.03,175.04,151.00,133.02$ & Luteolin & PT204043 & ReSpect \\
\hline 18 & 27.7 & 315.05 & $300.02,271.02,255.03$ & Isorhamnetin & PM007432 & ReSpect \\
\hline 19 & 29.5 & 269.04 & $225.05,151.00,117.03$ & Apigenin & PT203930 & ReSpect \\
\hline
\end{tabular}

No = number of peak in Fig. 9, RT = retention time, Mass = mass of precursor ion, MS/MS = fragment spectra obtained at -30 eV, Accession = accession number in database, Source $=$ database used, $n$. i. $=$ not identified, mod. $=$ modified

biofilms are found to be the major causative agent of many intestinal infections, for recurrent urinary tract infections, and it also responsible for indwelling medical device-related infectivity [43]. C. albicans is one of the very few fungal species causing disease in humans. These infections range from superficial mucosal and dermal infections, such as thrush, vaginal yeast infections, and diaper rash, to vascular catheters and dental implants infections [44].

The bioactive properties of the seagrass species selected in this work are well known, and have been reported in detail by several authors [45-47]. However, until now attention has mainly focused on the antimicrobial activity of seagrass extracts, which, through disk diffusion assays, were investigated not in their capacity as biofilm-forming microorganisms but in their planktonic state. Using lethal concentrations, Umamaheshwari et al. [46] reported the antibacterial activity of $H$. ovalis and $H$. pinifolia extracts, obtained using different solvents, against different microbial strains, recording maximum antibacterial activity by the ethanol extract of $H$. pinifolia. Instead, Choi et al. [48] reported the antimicrobial properties of Zostera marina methanol extract and its organic solvent fractions on three human skin pathogens (Staphylococcus aureus, S. epidermidis and C. albicans), and Natrah et al. [47] reported the antibacterial properties of methanol extracts of $E$. acoroides and other seagrass and seaweed species on different aquaculture pathogens (Aeromonas hydrophila, Vibrio alginolyticus, $V$. parahaemolyticus, $V$. anguillarum and others).

In contrast, to the best of our knowledge, no papers have investigated the antibiofilm activity of Enhalus acoroides, Halodule pinifolia and Halophila ovalis at non-lethal concentrations against bacterial (E. coli) and 
a

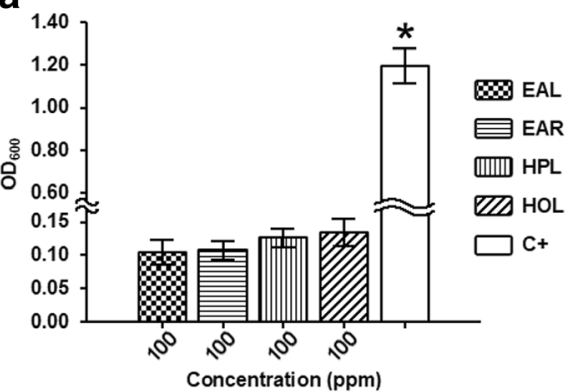

b

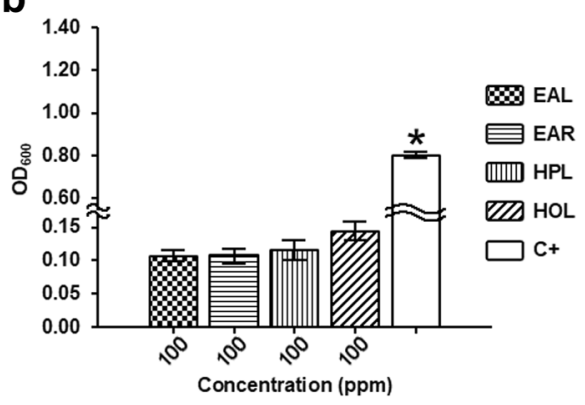

Fig. 3 E. coli (a) and C. albicans (b) planktonic growth without (positive control) and with each seagrass extract at 100 ppm. The positive control was set up with mineral medium supplemented with glucose at $5 \mathrm{~g} / \mathrm{l}$. Stars indicate statistically significant differences (Tukey's HSD, $p \leq 0.05$ ) between the means of three independent replicates. $(\mathrm{EAL}=$ Enhalus acoroides leaf; $\mathrm{EAR}=$ Enhalus acoroides root; $\mathrm{HPL}=\mathrm{Halodule} \mathrm{pinifolia} \mathrm{leaf;} \mathrm{HOL}$ $=$ Halophila ovalis leaf; $\mathrm{C}+=$ Positive control)

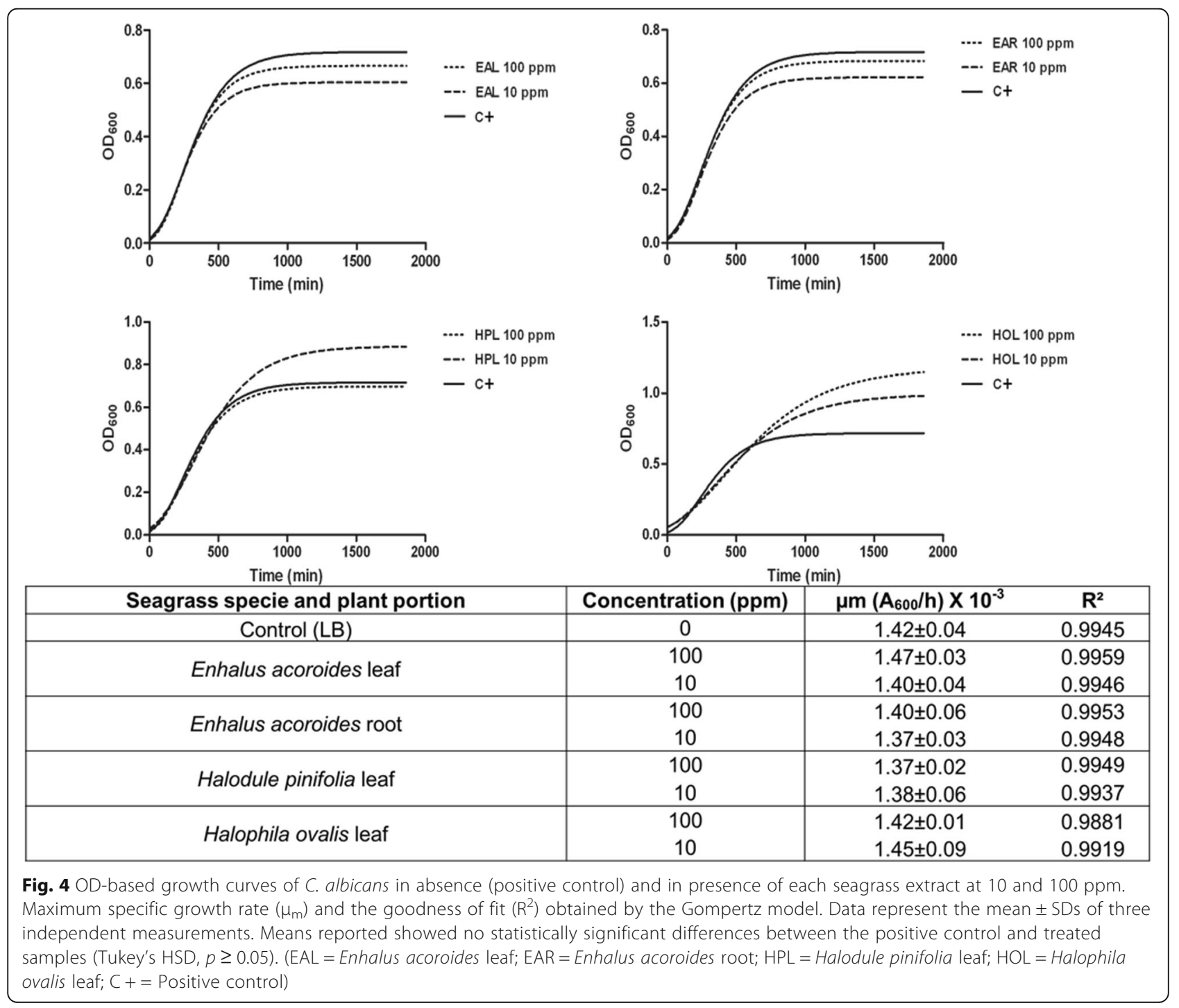




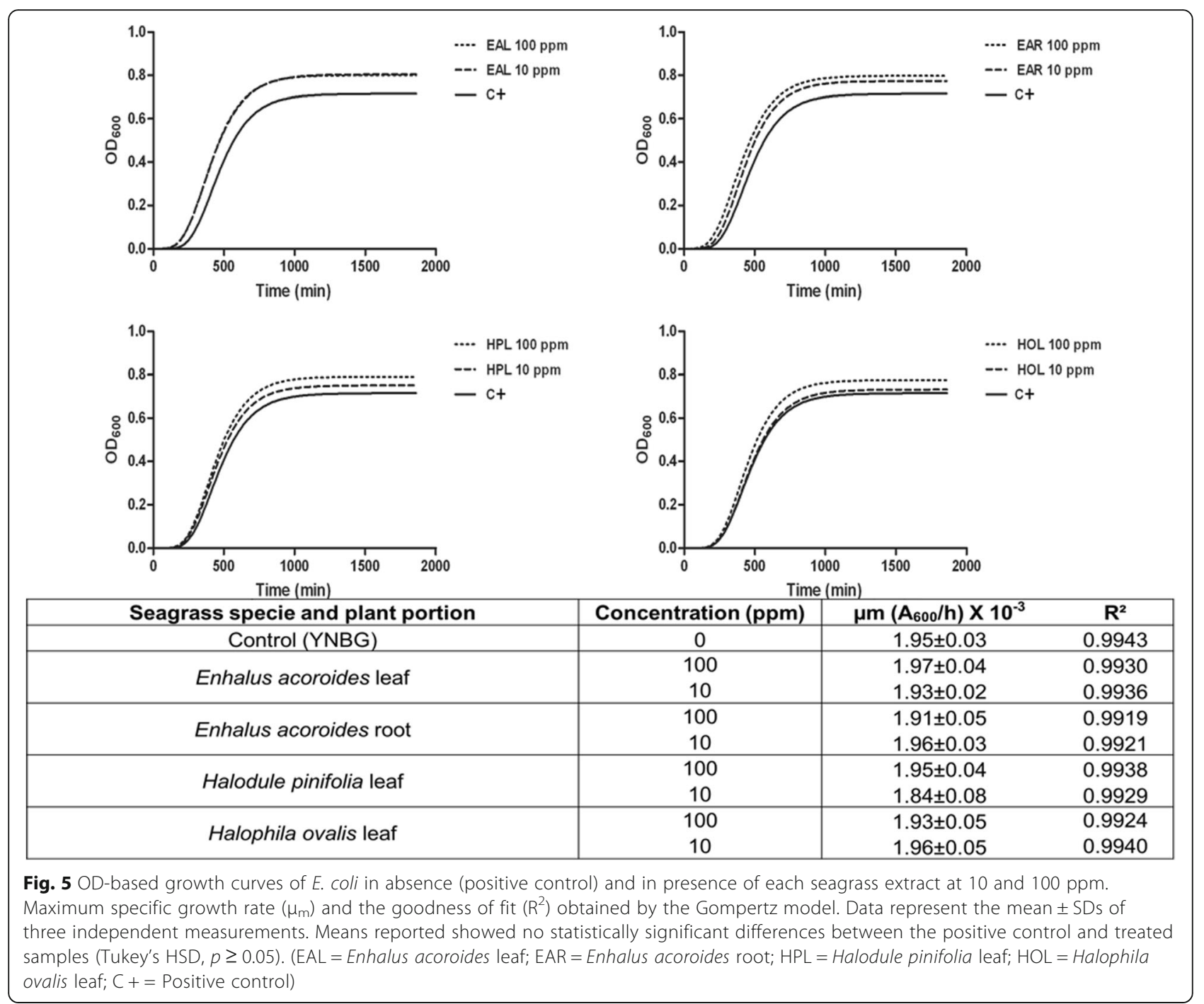

fungal (C. albicans) biofilms. To this end, methanol extracts, obtained from different organs of three seagrass species (namely, Enhalus acoroides leaves and roots, Halophila ovalis leaves and Halodule pinifolia leaves) were screened for their ability to modulate biofilm genesis without killing cells. Methanol was used as the extraction solvent, having been previously reported as the most effective solvent to obtain high concentrations of bioactive compounds with antibacterial activity from seagrasses, compared to other extraction solvents $[45,49,50]$.

Before evaluating the antibiofilm activity, the extracts, at concentrations of $100 \mathrm{mg} / \mathrm{l}$, were first proved to not act as a carbon and energy source nor to affect the cellular growth of $C$. albicans and E. coli. Therefore, concentrations $\leq 100 \mathrm{mg} / \mathrm{l}$ plant extract were used in the subsequent studies.

With the aim of investigating the effects of seagrass extracts on cell adhesion to surfaces, the first step of biofilm formation, microtiter based assays were performed. The results revealed excellent anti-adhesion activity for $E$. acoroides leaf extract, reducing fungal coverage up to $74 \%$ and bacterial coverage up to $61 \%$ at 0.01 and $10 \mathrm{mg} / \mathrm{l}$, respectively. Therefore, $0.01 \mathrm{mg} / \mathrm{l}$ and $10 \mathrm{mg} / \mathrm{l}$ E. acoroides leaf extract were chosen as the best non-biocidal concentrations for $C$. albicans and $E$. coli respectively, and were used in the subsequent studies. These concentrations significantly decreased the number of adhered cells on a hydrophobic surface, more so than on the hydrophilic one. Previous studies had highlighted the preference for hydrophobic surfaces, these reporting a decreased adhesion on the hydrophobic surface compared to the hydrophilic [51, 52]. This is probably due to the hydrophobic nature of the aerial surfaces of plants [53].

In the present study the anti-adhesion activity of the seagrass extracts was dose-dependent, but the highest concentrations did not correspond to those with the 


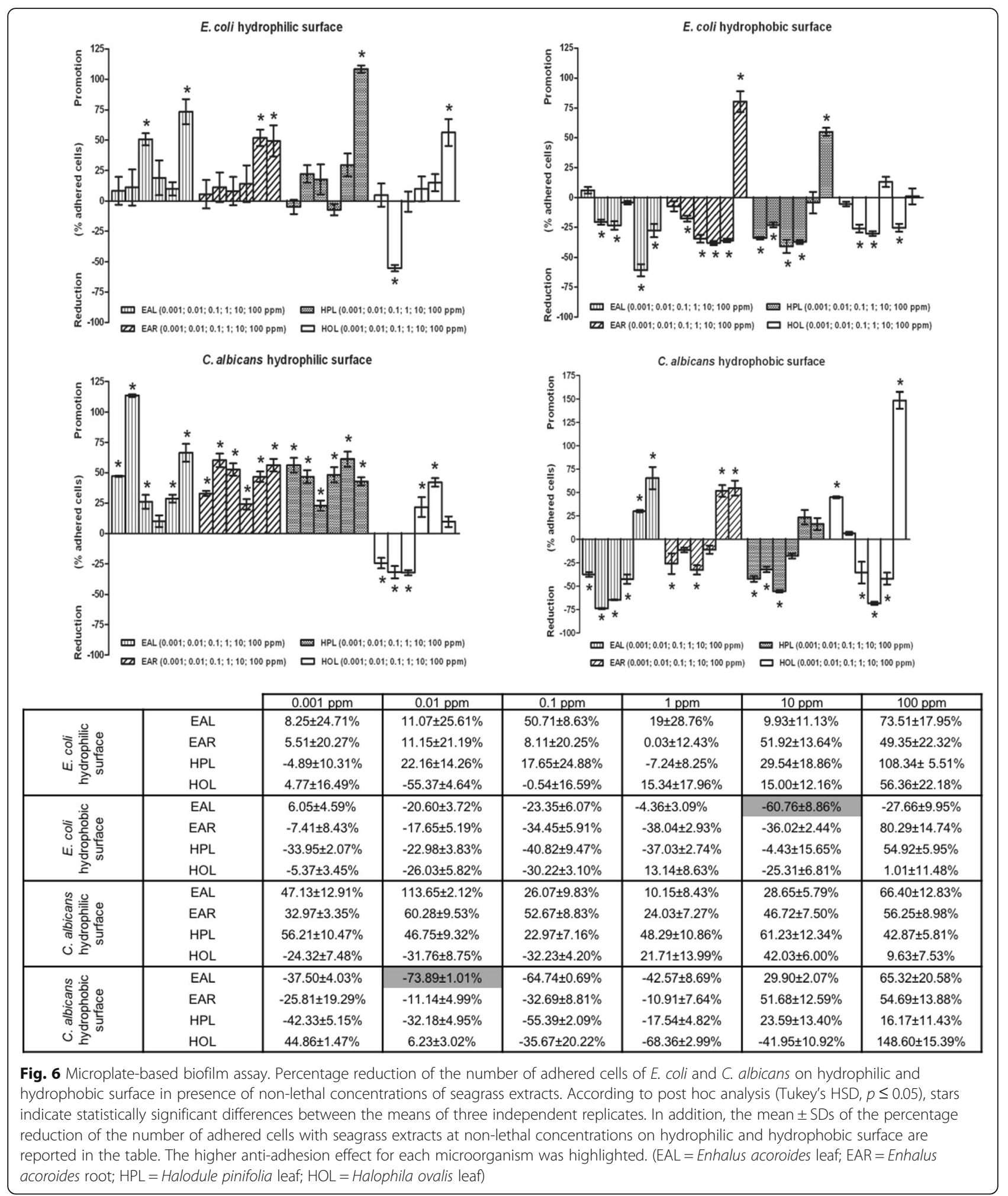

best performance. Indeed, several studies have reported a weak activity of the compounds at low and high concentrations, and excellent activity at intermediate concentrations [54]. Such a response, widely known in literature, is defined as hormesis, an adaptive behavior of microorganisms to provide resistance to environmental stress and improve the allocation of resources to ensure cell stability $[19,55]$. 
a

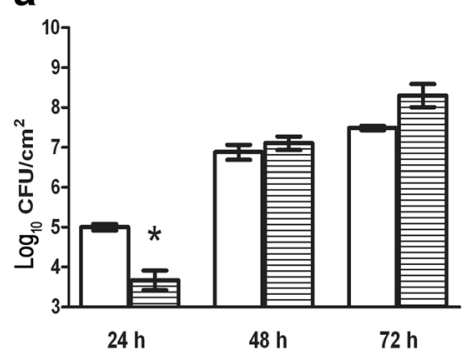

b

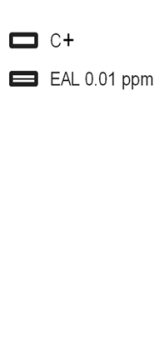

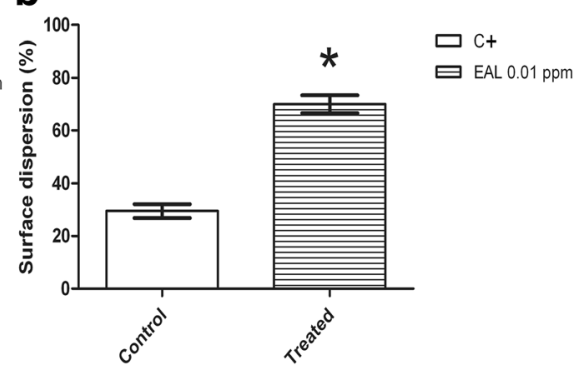

Fig. 7 CDC biofilm growth on polycarbonate coupons (a) and biofilm dispersion rate (b) of C. albicans in absence (positive control) and in presence (treated) of 0.01 ppm of Enhalus acoroides leaf extract. Stars indicate statistically significant differences (Tukey's HSD, $p \leq 0.05$ ) between the means of three independent replicates. ( $+=$ Positive control; $E A L=$ Enhalus acoroides leaf)

To further explore the effect of the most promising seagrass extract on biofilm development and detachment, CDC reactors were employed to reproduce biofilm at the solid/liquid interface, while for the assessment of the antibiofilm effect in the adhesion phase microplate-based biofilm assays are the most suitable [41, 56, 57]. In this study, a significant reduction in fungal coverage (up to $26.77 \pm 9.01 \%$ ) after $24 \mathrm{~h}$ (static adhesion phase) was observed in presence of $0.01 \mathrm{mg} / \mathrm{l}$ E. acoroides leaf extract. This result confirms the anti-adhesion activity observed in microtiter assays. Coupons collected after 48 and $72 \mathrm{~h}$ showed no significant differences between treated and control samples.

In order to assess the possibility of $0.01 \mathrm{mg} / \mathrm{l} E$. acoroides leaf extract to promote $C$. albicans biofilm-detachment from the surface of coupons, a biofilm dispersion assay was performed. Results showed a significant increase in the number of dispersed cells in the treated biofilm, compared with the untreated $(70 \pm 6.83 \%)$, suggesting a further mechanism of action for the seagrass extract as biofilm dispersing agent. In fact, the phase of biofilm dispersion could be an interesting target for the development of new antibiofilm strategies, forcing the planktonic state and reestablishing the efficacy of traditional antimicrobial agents $[4,58]$. Literature with information related to C. albicans biofilm dispersion is scarce. Farnesol and cis-2-decenoic acid showed dispersion-promotion of microcolonies of C. albicans biofilm $[58,59]$. In addition, Villa et al. [60] reported that non-lethal concentrations of Muscari comosum ethanol bulb extract can modulate yeast adhesion and subsequent biofilm development on abiotic surfaces, and such concentrations could provide an extracellular signal responsible for biofilm dispersion.

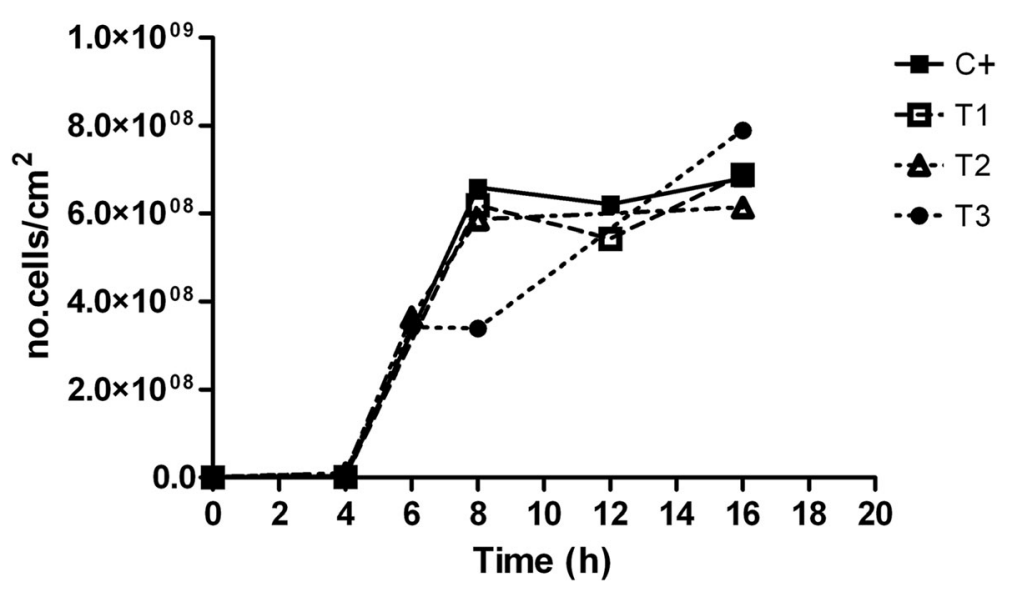

Fig. 8 Biofilm growth at the solid/air interface. E. coli biofilm grown on polycarbonate membrane under three experimental conditions: i) treatment 1: growth in contact with $1 \mathrm{ml}$ of LB with $10 \mathrm{ppm}$ of E. acoroides leaf extract; ii) treatment 2: overnight culture grown with 10 ppm of E. acoroides leaf extract and then growth in contact with $1 \mathrm{ml}$ of LB; iii) treatment 3: overnight culture grown with 10 ppm of E. acoroides leaf extract and growth in contact with $1 \mathrm{ml}$ of LB with $10 \mathrm{ppm}$ of E. acoroides leaf extract. In the positive control, microorganisms grew in $1 \mathrm{ml}$ LB inside a basolateral well without the extract. Data obtained were divided by the area of the membrane, and means were reported. The experiment was repeated three times. $(\mathrm{T} 1=$ treatment $1 ; \mathrm{T} 2=$ treatment $2 ; \mathrm{T} 3=$ treatment $3 ; \mathrm{C}+=$ Positive control) 


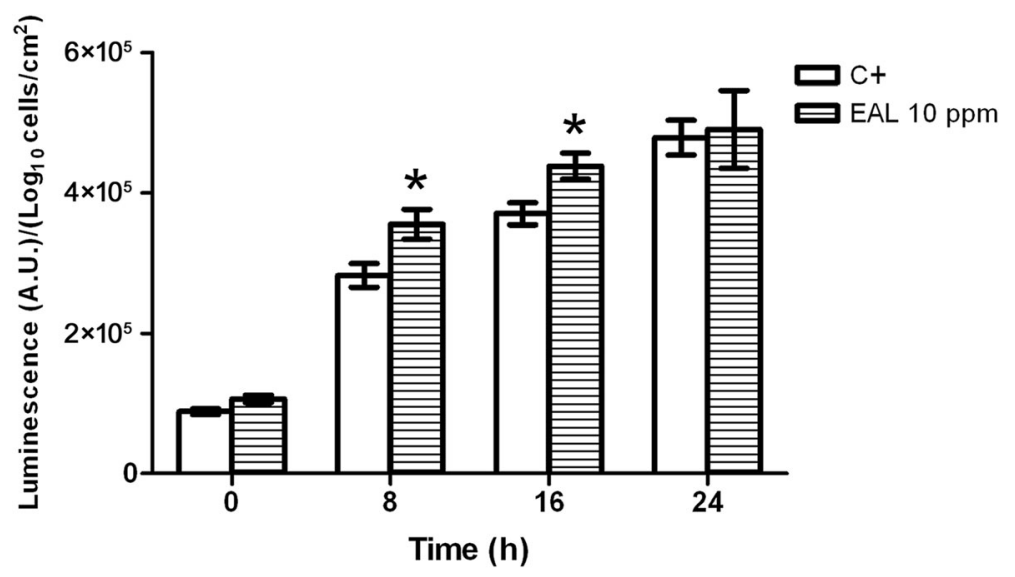

Fig. 9 Relative luminescence emitted by Vibrio harveyi in absence (positive control) and in presence of $10 \mathrm{ppm}$ of E. acoroides leaf extract for $24 \mathrm{~h}$ The relative luminescence has been calculated by normalizing luminescence by the number of adhered cells. Stars indicate statistically significant differences (Tukey's HSD, $\mathrm{p} \leq 0.05$ ) between the means of three independent replicates. ( $C+=$ Positive control; EAL = Enhalus acoroides leaf)

For E. coli, the CDC reactor was not suitable to evaluate the possible effects of the extracts on the biofilm stages. Also other authors have reported the poor biofilm formation exhibited by $E$. coli K-12 strain under hydrodynamic conditions [61-63]. The effect of $10 \mathrm{mg} / \mathrm{l}$ of $E$. acoroides leaf extract on $E$. coli biofilm formation was then evaluated using a membrane-supporting biofilm reactor, which allowed the formation of a biofilm at the solid/air interface. This technique forced the cells to attach to a surface, a feature that allowed direct investigation of the effect of the selected extract on the development of the biofilm, whilst bypassing the effect on the adhesion phase.

No significant reduction in the number of viable cells during biofilm formation on the membrane treated with the extract, compared to the untreated, after $18 \mathrm{~h}$ in all the experimental conditions was observed. Treatment 3 showed a growth rate slowdown in the interval $6-8 \mathrm{~h}$, in which $E$. coli cells were in contact with the extract during both overnight growth and biofilm formation (reduction of cellular growth, compared to the control, up to $48.64 \pm 4.02 \%)$. Interestingly, treatment 3 showed a biphasic growth curve compared with the growth curves of the other treatments, a trend that could be explained by the bioluminescence produced by $V$. harvey. As signaling molecules play an important role in biofilm development and detachment, the effects of $10 \mathrm{mg} / \mathrm{l}$ of $E$. acoroides leaf extract were investigated using $V$. harveyi, suggesting other possible antibiofilm mechanisms of action of compounds in the chosen seagrass extract. The results revealed that at time $8 \mathrm{~h}$, the samples treated with the leaf extract showed a significant increase in the relative luminescence emitted, compared to the control $(25.75 \pm 7.49)$. Villa et al. [64] reported an increase of autoinducer-2 (AI-2) activity and a reduction in biofilm formation in $E$. coli cells treated with zosteric acid, a phenolic compound occurring in the seagrass Zostera marina. In fact, it has been hypothesized that the accumulation of AI-2 above a threshold level leads to reduced biofilm formation due to the induction of a hypermotile phenotype that is unable to adhere to the surface [64]. Huber et al. [65] demonstrated that some polyphenolic compounds containing a gallic acid residue commonly produced by some plant species inhibited intercellular communication in bacteria. Truchado et al. [66] reported the ability of some phytochemical compounds (cinnamaldehyde, ellagic acid, resveratrol, rutin and pomegranate extract) to interfere with the quorum sensing system of Yersinia enterocolitica and Erwinia cartovora.

It has been well known that the antibiofilm activity of plant extracts is closely linked with the content of secondary metabolites, such as phenols and/or flavonoids, which represent the total amount of phenolic compounds in a plant extract [13]. The phenolic compound content is also deeply associated with the antioxidant activity of plant extracts [67]. Therefore, we determined the total phenolic acid (TPC) and flavonoid (TFC) content and the antioxidant activity (ORAC) of methanolic extracts in order to highlight features of the most promising antibiofilm extract, the E. acaroides leaf extract. Results show that E. acaroides leaf extract presents the lower TPC and TFC values compared to other seagrasse extracts. Although the low content of phenolic compounds, the $E$. acaroides leaf extract displays a higher ORAC value compared to the root extract. This indicates the abundance of other, non-phenolic compounds with antioxidant capacity in the leaves of $E$. acoroides. Cattò et al. [39] suggested the importance of antioxidant compounds in hindering biofilm formation. The researcher discovered that the mechanism of action behind the antibiofilm performance 
of zosteric acid, a secondary metabolite of the seagrass Zostera marina, is related to the antioxidant activity of the molecule, and its interaction with the WrbA protein responsible maintaining cellular homeostasis and defense against oxidative stress.

To gain more insight into possible antibiofilm compounds in the seagrass extracts, individual substances in the methanolic extract were analyzed by LC-MS. Preliminary analysis shows that the phytochemical profile of the $E$. acaroides leaf extract is mainly characterized by the presence of the flavones apigenin and luteolin, three kaempferol derivates and the carboxylic acids benzoic and azelaic acid. This unique quantitative and qualitative chemical composition confers antibiofilm properties to the $E$. acaroides leaf extract.

Some of these compounds have shown to exhibit antibiofilm properties at non-lethal concentrations. Kaempferol, apigenin and luteolin from red wine reduced biofilm formation of methicillin-sensitive $S$. aureus significantly [68]. Sánchez et colleagues [69] reported that sub-lethal concentrations of plant extracts inhibit $E$. coli and $S$. aureus biofilms. The antibiofilm properties of the extracts were associated to the presence of flavonoids, such as kaempferol and apigenin, which modulate bacterial cell-cell communication by suppressing the activity of the autoinducer-2 [70]. However, we should keep in mind that the antibiofilm effects of plant extracts could be the result of interactions among different components of the extract at specific concentrations, and not only due to the effects of a single, predominant compound $[4,71]$.

\section{Conclusions}

In conclusion, the $E$. acoroides leaf extract proved to be the most promising extract among those tested. Indeed, the selected non-lethal concentrations of E. acoroides leaf extract were found to exert an antibiofilm effect on C. albicans and E. coli biofilm in the first phase of biofilm genesis, opening up the possibility of developing preventive strategies to hinder the adhesion of microbial cells to surfaces. The leaf extract also affected the dispersion and maturation steps in C. albicans and $E$. coli respectively, suggesting an important role in cell signaling processes. These effects could be explained by the presence of active compounds like kaempferol and apigenin at specific concentrations in the extracts of $E$. acoroides, which are known to possess biofilm inhibiting properties. Furthermore, there could be a synergistic action of these flavonoids with other compounds occurring in the plant, enhancing the global antibiofilm effect. Currently, the leaf extract is being investigated with the objective of testing fractions for identifying the active compounds and to better understand the mechanisms of action of this seagrass species.

\section{Acknowledgments \\ We would like to thank Dr. Vy Xuan Nguyen for the identification and collection of the seagrass samples in Vietnam used in this work.}

\section{Funding}

This work was supported by the German-Italian bilateral project "Bioactive secondary compounds from halophyte species inhibit biofilm formation of plant-pathogenic microorganisms on plant surfaces" (SAB-HAL), MIUR-DAAD Joint Mobility Program, ID-57265315.

\section{Availability of data and materials}

The datasets used and/or analyzed during the current study available from the corresponding author on reasonable request.

\section{Authors' contributions}

DVL performed the biological experiments and wrote the manuscript. GY extracted and analyzed the crude extracts from the plants by MS. CC participated in the design of the study and provided technical advices and lab supports. VF conceived, designed and coordinated the study. VF contributed substantially to the writing and revising of the manuscript. CF and PJ participated in the design of the study, in discussions and reviewed the manuscript. All authors read and approved the final manuscript.

\section{Competing interest}

The authors declare that they have no competing interests.

Ethics approval and consent to participate Not applicable.

\section{Publisher's Note}

Springer Nature remains neutral with regard to jurisdictional claims in published maps and institutional affiliations.

\section{Author details}

'Dipartimento di Scienze per gli Alimenti, la Nutrizione e l'Ambiente, Università degli Studi di Milano, via Celoria 2, 20133 Milan, Italy. ${ }^{2}$ Institute of Botany, Leibniz University Hannover, Herrenhäuserstr. 2, D-30419 Hannover, Germany.

Received: 16 December 2017 Accepted: 15 May 2018

Published online: 30 May 2018

\section{References}

1. Costerton JW. Introduction to biofilm. Int J Antimicrob Agents. 1999;11:217-21.

2. Hall-Stoodley L, Costerton WJ, Stoodley P. Bacterial biofilms: from the natural environment to infectious diseases. Nat Rev Microbiol. 2004;2:95108. https://doi.org/10.1038/nrmicro821.

3. Rayner J, Veeh R, Flood J. Prevalence of microbial biofilms on selected fresh produce and household surfaces. Int J Food Microbiol. 2004;95:29-39.

4. Villa F, Villa S, Gelain A, Cappitelli F. Sub-lethal activity of small molecules from natural sources and their synthetic derivatives against biofilm forming nosocomial pathogens. Curr Top Med Chem. 2013;13(24):3184-204.

5. Macià MD, Rojo-Molinero E, Oliver A. Antimicrobial susceptibility testing in biofilm-growing bacteria. Clin Microbiol Infect. 2014;20(10):981-90. https:// doi.org/10.1111/1469-0691.12651.

6. Percival SL, Suleman L, Vuotto C, Donelli G. Healthcare-associated infections, medical devices and biofilms: risk. tolerance and control J Med Microbiol. 2015;64(Pt 4):323-34. https://doi.org/10.1099/jmm.0.000032.

7. Brown GD, Denning DW, Gow NA, Levitz SM, Netea MG, White TC. Hidden killers: human fungal infections. Sci Transl Med. 2012;4:165rv113. https://doi. org/10.1126/scitranslmed.3004404.

8. Akbari F, Kjellerup BV. Elimination of bloodstream infections associated with Candida albicans biofilm in intravascular catheters. Pathogens 2015;4(3):45769. https://doi.org/10.3390/pathogens4030457.

9. Stewart PS, Costerton JW. Antibiotic resistance of bacteria in biofilms. Lancet. 2001;358:135-8. https://doi.org/10.1016/S0140-6736(01)05321-1.

10. Smith K, Hunter IS. Efficacy of common hospital biocides with biofilms of multi-drug resistant clinical isolates. J Med Microbiol. 2008;57:966-73. https://doi.org/10.1099/jmm.0.47668-0.

11. Lebeaux D, Ghigo JM, Beloin C. Biofilm-related infections: bridging the gap between clinical management and fundamental aspects of recalcitrance 
toward antibiotics. Microbiol Mol Biol Rev. 2014;78(3):510-43. https://doi. org/10.1128/MMBR.00013-14.

12. Chung PY. Plant-derived compounds as potential source of novel antibiofilm agents against Pseudomonas aeruginosa. Curr Drug Targets. 2017; 18(4):414-20. https://doi.org/10.2174/1389450117666161019102025.

13. Choi HA, Cheong DE, Lim HD, Kim WH, Ham MH, Oh MH, Wu Y, Shin HJ, Kim GJ. Antimicrobial and anti-biofilm activities of the methanol extracts of medicinal plants against dental pathogens Streptococcus mutans and Candida albicans. J Microbiol Biotechnol. 2017;27(7):1242-8. https://doi.org/ 10.4014/jmb.1701.01026.

14. da Silva DT, Herrera R, Batista BF, Heinzmann BM, Labidi J. Physicochemical characterization of leaf extracts from Ocotea lancifolia and its effect against wood-rot fungi. Int Biodeterior Biodegradation. 2017;117:158-70. doi.org/10. 1016/j.ibiod.2016.12.007

15. Teanpaisan R, Kawsud P, Pahumunto N, Puripattanavong J. Screening for antibacterial and antibiofilm activity in Thai medicinal plant extracts against oral microorganisms. J Tradit Complement Med. 2017;7(2):172-7. doi.org/10. 1016/j.jtcme.2016.06.007

16. Abiala M, Olayiwola J, Babatunde O, Aiyelaagbe O, Akinyemi S. Evaluation of therapeutic potentials of plant extracts against poultry bacteria threatening public health. BMC Complement Altern Med. 2016;16(1):417.

17. Bisi-Johnson MA, Obi CL, Samuel BB, Eloff JN, Okoh Al. Antibacterial activity of crude extracts of some south African medicinal plants against multidrug resistant etiological agents of diarrhoea. BMC Complement Altern Med. 2017;17(1):321. https://doi.org/10.1186/s12906-017-1802-4.

18. Elisha IL, Botha FS, McGaw $\sqcup$, Eloff JN. The antibacterial activity of extracts of nine plant species with good activity against Escherichia coli against five other bacteria and cytotoxicity of extracts. BMC Complement Altern Med. 2017;17(1):133. https://doi.org/10.1186/s12906-017-1645-z.

19. Villa F, Cappitelli F. Plant-derived bioactive compounds at sub-lethal concentrations: towards smart biocide-free antibiofilm strategies. Phytochem Rev. 2013;12:245-54. https://doi.org/10.1007/s11101-013-9286-4.

20. Flowers TJ, Colmer TD. Salinity tolerance in halophytes. New Phytol. 2008; 179:945-63. https://doi.org/10.1111/j.1469-8137.2008.02531.x.

21. Flowers TJ, Colmer TD. Plant salt tolerance: adaptations in halophytes. Ann Bot. 2015:115327-31. https://doi.org/10.1093/aob/mcu267.

22. Joshi R, Ramanarao MV, Bedre R, Sanchez L, Pilcher W, Zandkarimi H, Baisakh N. Salt adaptation mechanisms of halophytes: improvement of salt tolerance in crop plants. In: Pandey GK, editor. Elucidation of abiotic stress signaling in plants. New York, NY: Springer; 2015. p. 243-79. https://doi.org/ 10.1007/978-1-4939-2540-7_9

23. Selmar D. Potential of salt and drought stress to increase pharmaceutical significant secondary compounds in plants. Landbauforschung. 2008;58: 139-44.

24. Ksouri R, Ksouri WM, Jallali I, Debez A, Magné C, Hiroko I, Abdelly C. Medicinal halophytes: potent source of health promoting biomolecules with medical, nutraceutical and food applications. Crit Rev Biotechnol. 2012; 32:289-326. https://doi.org/10.3109/07388551.2011.630647.

25. Boestfleisch C, Wagenseil NB, Buhmann AK, Seal CE, Wade EM, Muscolo A, Papenbrock J. Manipulating the antioxidant capacity of halophytes to increase their cultural and economic value through saline cultivation. AoB Plants. 2014;6:plu046. https://doi.org/10.1093/aobpla/plu046.

26. Hua KF, Hsu HY, Su YC, Lin IF, Yang SS, Chen YM. Study on the antinflammatory activity of methanol extract from seagrass Zostera japonica. J Agric Food Chem. 2006;54:306-11. https://doi.org/10.1021/ff0509658.

27. Gokce G, Haznedaroglu MZ. Evaluation of antidiabetic, antioxidant and vasoprotective effects of Posidonia oceanica extract. J Ethnopharmacol. 2008;115:122-30

28. Kannan RRR, Arumugam R, Anantharaman P. Chemical composition and antibacterial activity of Indian seagrasses against urinary tract pathogens. Food Chem. 2012;135:2470-3. https://doi.org/10.1016/j.foodchem.2012.07.070.

29. Nguyen XV, Höfler S, Glasenapp Y, Thangaradjou T, Lucas C, Papenbrock J. New insights into the DNA barcoding of seagrasses. Syst Biodivers. 2015;13: 496-508. https://doi.org/10.1080/14772000.2015.1046408.

30. Lucas C, Thangaradjou T, Papenbrock J. Development of a DNA barcoding system for seagrasses: successful but not simple. PLoS One. 2012;7:e29987. https://doi.org/10.1371/journal.pone.0029987.

31. Dudonné S, Vitrac $X$, Coutière $P$, Woillez M, Mérillon JM. Comparative study of antioxidant properties and total phenolic content of 30 plant extracts of industrial interest using DPPH, ABTS, FRAP, SOD, and ORAC assays. J Agric Food Chem. 2009;57:1768-74. https://doi.org/10.1021/jf803011r.
32. Dewanto V, Wu X, Adom KK, Liu RH. Thermal processing enhances the nutritional value of tomatoes by increasing total antioxidant activity. J Agric Food Chem. 2002;50:3010-4. https://doi.org/10.1021/jf0115589.

33. Huang D, Ou B, Hampsch-Woodill M, Flanagan JA, Prior RL. Highthroughput assay of oxygen radical absorbance capacity (ORAC) using a multichannel liquid handling system coupled with a microplate fluorescence reader in 96-well format. J Agric Food Chem. 2002;50(16): 4437-44. https://doi.org/10.1021/jf0201529.

34. Gillespie KM, Chae JM, Ainsworth EA. Rapid measurement of total antioxidant capacity in plants. Nat Protoc. 2007;2(4):867-70. https://doi.org/ 10.1038/nprot.2007.100.

35. Horai $H$, Arita M, Kanaya $S$, Nihei $Y$, Ikeda $T$, Suwa $K$, Ojima $Y$, Tanaka K, Tanaka S, Aoshima K, Oda Y, Kakazu Y, Kusano M, Tohge T, Matsuda F, Sawada Y, Yokota Hirai M, Nakanishi H, Ikeda K, Akimoto N, Maoka T, Takahashi H, Ara T, Sakurai N, Suzuki H, Shibata D, Neumann S, lida T, Tanaka K, Funatsu K, Matsuura F, Soga T, Taguchi R, Saito K, Nishioka T. MassBank: a public repository for sharing mass spectral data for life sciences. J Mass Spectrom. 2010;45:703-14. https://doi.org/10. 1002/jms.1777.

36. Sawada Y, Nakabayashi R, Yamada Y, Suzuki M, Sato M, Sakata A, Akiyama K, Sakurai T, Matsuda F, Aoki T, Hirai MY, Saito K. RIKEN tandem mass spectral database (ReSpect) for phytochemicals: a plant-specific MS/MS-based data resource and database. Phytochemistry. 2012;82:38-45. https://doi.org/10. 1016/j.phytochem.2012.07.007.

37. Zwietering $\mathrm{MH}$, Jongenburger I, Rombouts FM, van't Riet $\mathrm{K}$. Modeling of the bacterial growth curve. Appl Environ Microbiol 1990;56:1875-1881.

38. Villa F, Albanese D, Giussani B, Stewart P, Daffonchio D, Cappitelli F. Hindering biofilm formation with zosteric acid. Biofouling. 2010;26:739-52. https://doi.org/10.1080/08927014.2010.511197.

39. Cattò C, Dell'Orto S, Villa F, Villa S, Gelain A, Vitali A, Marzano V, Baroni S, Forlani F, Cappitelli F. Unraveling the structural and molecular basis responsible for the anti-biofilm activity of zosteric acid. PLoS One. 2015; 10(7):e0131519. https://doi.org/10.1371/journal.pone.0131519.

40. Villa F, Pitts B, Stewart PS, Giussani B, Roncoroni S, Albanese D. Efficacy of zosteric acid sodium salt on the yeast biofilm model Candida albicans. Microb Ecol. 2011;62:584-98. https://doi.org/10.1007/ s00248-011-9876-x.

41. Cattò C, Grazioso G, Dell'Orto S, Gelain A, Villa S, Marzano V, Vitali A, Villa F, Cappitelli F, Forlani F. The response of Escherichia coli biofilm to salicylic acid. Biofouling. 2017;33:235-51. https://doi.org/10.1080/08927014.2017.1286649.

42. Garuglieri E, Meroni E, Cattò C, Villa F, Cappitelli F, Erba D. Effects of sublethal concentrations of silver nanoparticles on a simulated intestinal prokaryotic-eukaryotic interface. Front Microbiol. 2018;8:2698. https://doi. org/10.3389/fmicb.2017.02698.

43. Sharma G, Sharma S, Sharma P, Chandola D, Dang S, Gupta S, Gabrani R. Escherichia coli biofilm: development and therapeutic strategies. J Appl Microbiol. 2016;121 (2):309-19. https://doi.org/10.1111/jam.13078. Epub 2016 Mar 11

44. Nobile CJ, Johnson AD. Candida albicans biofilms and human disease. Annu Rev Microbiol. 2015;69:71-92. https://doi.org/10.1146/annurev-micro091014-104330.

45. Kumar SC, Sarada DVL, Gideon TP, Rengasamy R. Antibacterial activity of three south Indian seagrasses, Cymodocea serrulata, Halophila ovalis and Zostera capensis. World J Microbiol Biotechnol. 2008;24(9):1989-92. https:/ doi.org/10.1007/s11274-008-9695-5.

46. Umamaheshwari R, Thirumaran G, Anantharaman P. Potential antibacterial activities from vellar estuary; south east coast of India. Adv Biomed Res. 2009;3:140-3.

47. Natrah FMI, Harah ZM, Japar Sidik NI, Syahidah A. Antibacterial activities of selected seaweed and seagrass from port Dickson coastal water against different aquaculture pathogens. Sains Malays. 2015; 44(9):1269-73.

48. Choi HG, Lee JH, Park HH, Sayegh FAQ. Antioxidant and antimicrobial activity of Zostera marina L. extract. Algae. 2009;24(3):179-84. https://doi. org/10.4490/algae.2009.24.3.179.

49. Lustigman B, Brown C. Antibiotic production by marine algae isolated from the New York/New Jersey coast. Bull Environ Contam Toxicol. 1991;46:32935. https://doi.org/10.1007/BF01688928.

50. Sastry VMVS, Rao GRK. Antibacterial substances from marine algae: successive extraction using benzene, chloroform and methanol. Bot Mar. 1994;37:357-60. https://doi.org/10.1515/botm.1994.37.4.357. 
51. Doss RP, Potter SW, Chastagner GA, Christian JK. Adhesion of nongerminated Botrytis cinerea conidia to several substrata. Appl Environ Microbiol. 1993;59: 1786-91.

52. Amiri A, Cholodowski D, Bompeix G. Adhesion and germination of waterborne and airborne conidia of Penicillium expansum to apple and inert surfaces. Physiol Mol Plant Pathol. 2005;67:40-8. https://doi.org/10.1016/j. pmpp.2005.07.003.

53. Koch K, Bhushan B, Barthlott W. Multifunctional surface structures of plants: an inspiration of biomimetics. Prog Mater Sci. 2009;54:137-78. https://doi. org/10.1016/j.pmatsci.2008.07.003.

54. Rickard AH, Palmer RJ, Blehert DS, Campagna SR, Semmelhack MF, Egland PG, Bassler BL, Kolenbrander PE. Autoinducer 2: a concentration-dependent signal for mutualistic bacterial biofilm growth. Mol Microbiol. 2006;60:144656. https://doi.org/10.1111/j.1365-2958.2006.05202.x.

55. Calabrese EJ, Baldwin LA. Hormesis: the dose-response revolution. Annu Rev Pharmacol Toxicol. 2003;43:175-97. https://doi.org/10.1146/annurev. pharmtox.43.100901.140223.

56. Williams DL, Woodbury KL, Haymond BS, Parker AE, Bloebaum RD. A modified CDC biofilm reactor to produce mature biofilms on the surface of PEEK membranes for an in vivo animal model application. Curr Microbiol. 2011;62:1657-63. https://doi.org/10.1007/s00284-011-9908-2.

57. Coffey BM, Anderson GG. Biofilm formation in the 96-well microtiter plate. Methods Mol Biol. 2014;1149:631-41. https://doi.org/10.1007/978-1-49390473-0_48.

58. Davies DG, Marques CN. A fatty acid messenger is responsible for inducing dispersion in microbial biofilms. J Bacteriol. 2009;191:1393-403. https://doi. org/10.1128/JB.01214-08.

59. Uppuluri P, Chaturvedi AK, Srinivasan A, Banerjee M, Ramasubramaniam AK, Köhler JR, Kadosh D, Lopez-Ribot JL. Dispersion as an important step in the Candida albicans biofilm developmental cycle. PLoS Pathog. 2010;6: e1000828. https://doi.org/10.1371/journal.ppat.1000828.

60. Villa F, Borgonovo G, Cappitelli F, Giussani B, Bassoli A. Sublethal concentrations of Muscari comosum bulb extract suppress adhesion and induce detachment of sessile yeast cells. Biofouling. 2012;28:1107-17. https://doi.org/10.1080/08927014.2012.734811.

61. Ghigo JM. Natural conjugative plasmids induce bacterial biofilm development. Nature. 2001;412:442-5. https://doi.org/10.1038/35086581.

62. Reisner A, Haagensen JA, Schembri MA, Zechner EL, Mølin S. Development and maturation of Escherichia coli K-12 biofilms. Mol Microbiol. 2003;48:93346. https://doi.org/10.1046/j.1365-2958.2003.03490.x.

63. Reisner A, Krogfelt KA, Klein BM, Zechner EL, Mølin S. 2006. In vitro biofilm formation of commensal and pathogenic Escherichia coli strains: impact of environmental and genetic factors. J Bacteriol. 2006;188:3572-81. https://doi. org/10.1128/JB.188.10.3572-3581.2006.

64. Villa F, Remelli W, Forlani F, Vitali A, Cappitelli F. Altered expression level of Escherichia coli proteins in response to treatment with the antifouling agent zosteric acid sodium salt. Environ Microbiol. 2012;14:1753-61.

65. Huber AB, Kolodkin AL, Ginty DD, Cloutier JF. Signaling at the growth cone: ligand-receptor complexes and the control of axon growth and guidance. Annu Rev Neurosci. 2003;26:509-63. https://doi.org/10.1146/annurev.neuro. 26.010302.081139.

66. Truchado P, Lopez-Galvez F, Gil MI, Tomas-Barberan FA, Allende A. Quorum sensing inhibitory and antimicrobial activities of honeys and the relationship with individual phenolics. Food Chem. 2009;115:1337-44. https://doi.org/10.1016/j.foodchem.2009.01.065.

67. Reis Giada ML. Food phenolic compounds: main classes, sources and their antioxidant power, oxidative stress and chronic degenerative diseases Jose Antonio Morales-Gonzalez, IntechOpen. 2013. https://doi.org/10.5772/51687. Available from: https://www.intechopen.com/books/oxidative-stress-andchronic-degenerative-diseases-a-role-for-antioxidants/food-phenoliccompounds-main-classes-sources-and-their-antioxidant-power.

68. Cho HS, Lee JH, Cho MH, Lee J. Red wines and flavonoids diminish Staphylococcus aureus virulence with anti-biofilm and anti-hemolytic activities. Biofouling. 2015;31(1):1-11. https://doi.org/10.1080/08927014. 2014.991319.

69. Sánchez E, Rivas Morales C, Castillo S, Leos-Rivas C, García-Becerra L, Mizael Ortiz Martínez D. Antibacterial and antibiofilm activity of methanolic plant extracts against nosocomial microorganisms. J Evid Based Complementary Altern Med. 2016, Article ID 1572697;2016:8. https://doi.org/10.1155/2016/ 1572697.
70. Vikram A, Jayaprakasha GK, Jesudhasan PR, Pillai SD, Patil BS. Suppression of bacterial cell-cell signalling, biofilm formation and type III secretion system by citrus flavonoids. J Appl Microbiol. 2010;109(2):515-27. https://doi.org/10. 1111/j.1365-2672.2010.04677.x.

71. Bazargani MM, Rohloff J. Antibiofilm activity of essential oils and plant extracts against Staphylococcus aureus and Escherichia coli biofilms. Food Control. 2016;61:156-64. https://doi.org/10.1016/j.foodcont.2015.09.036.

\section{Ready to submit your research? Choose BMC and benefit from:}

- fast, convenient online submission

- thorough peer review by experienced researchers in your field

- rapid publication on acceptance

- support for research data, including large and complex data types

- gold Open Access which fosters wider collaboration and increased citations

- maximum visibility for your research: over $100 \mathrm{M}$ website views per year

At BMC, research is always in progress.

Learn more biomedcentral.com/submissions 